Article

\title{
Diversity, Host Plants and Potential Distribution of Edible Saturniid Caterpillars in Kenya
}

\author{
Elizabeth Siago Kusia $\left.{ }^{1,2}{ }^{(}\right)$, Christian Borgemeister ${ }^{2}{ }^{-}$, Fathiya M. Khamis ${ }^{1}$, Robert S. Copeland ${ }^{1,3}$, \\ Chrysantus M. Tanga ${ }^{1} \mathbb{D}$, Fidelis Levi Ombura ${ }^{1}$ and Sevgan Subramanian ${ }^{1, * \mathbb{D}}$ \\ 1 International Centre of Insect Physiology and Ecology (icipe), Nairobi 00100, Kenya; ekusia@icipe.org (E.S.K.); \\ fkhamis@icipe.org (F.M.K.); rcopeland@icipe.org (R.S.C.); ctanga@icipe.org (C.M.T.); \\ lombura@icipe.org (F.L.O.) \\ 2 Centre for Development Research (ZEF), University of Bonn, 53113 Bonn, Germany; cborgeme@uni-bonn.de \\ 3 Department of Entomology, National Museum of Natural History, Smithsonian Institution, \\ Washington, DC 20013, USA \\ * Correspondence: ssubramania@icipe.org; Tel.: +254-20-8632159
}

Citation: Kusia, E.S.; Borgemeister, C.; Khamis, F.M.; Copeland, R.S.;

Tanga, C.M.; Ombura, F.L.;

Subramanian, S. Diversity, Host Plants and Potential Distribution of Edible Saturniid Caterpillars in Kenya. Insects 2021, 12, 600. https:// doi.org/10.3390/insects12070600

Academic Editor: Frederic Francis

Received: 6 April 2021

Accepted: 16 June 2021

Published: 1 July 2021

Publisher's Note: MDPI stays neutral with regard to jurisdictional claims in published maps and institutional affiliations.

Copyright: (c) 2021 by the authors. Licensee MDPI, Basel, Switzerland. This article is an open access article distributed under the terms and conditions of the Creative Commons Attribution (CC BY) license (https:// creativecommons.org/licenses/by/ $4.0 /)$.
Simple Summary: Edible insects are a traditional food source with economic benefits in sub-Saharan Africa. Caterpillars are the most popular edible insects in this region. We focus on caterpillars in the family Saturniidae. Saturniids are big colorful caterpillars with spines on their bodies, usually found in shrubs and trees. They are rich in proteins, vitamins, and minerals. Despite their economic importance, little is known about their diversity, host plants, distribution, and potential effect of climate change on edible saturniid caterpillars in Africa. The aim of this study is to identify edible saturniids, their host plants, their current distribution and to predict the possible effects of climate change on their distribution. We documented seven species of edible saturniids namely Gonimbrasia zambesina, Gonimbrasia krucki, Bunaea alcinoe, Gonimbrasia cocaulti, Gonimbrasia belina, Gynanisa nigra and Cirina forda. These caterpillars mostly occur twice a year during the rainy seasons and feed on specific host plants. Predictive distribution models revealed that B. alcinoe, and C. forda are mostly found in tropical and sub-tropical regions in Africa. However, climate change could cause a slight decrease in their population by the year 2050. This information will guide conservation efforts and ensure sustainable use of edible saturniid caterpillars as food.

Abstract: The promotion of edible insects, including saturniid caterpillars as potential food source is widely gaining momentum. They are adequately rich in nutrients such as proteins, amino acids, fatty acids, and micronutrients. Despite saturniids being a traditional food source with economic benefits, information on their diversity, host plants and their potential distribution in Africa are lacking, which this study seeks to address. Edible saturniids and their host plants were characterized using specific primers (LepF1/LepR1 and 3F_KIM_F/1R_KIM_R, respectively). Maximum entropy (MaxENT) and GARP (genetic algorithm for ruleset production) models were used to characterize the potential distribution of commonly consumed saturniids under current and future climate scenarios. Seven species of saturniids were recorded from 11 host plants in Kenya: Gonimbrasia zambesina, Gonimbrasia krucki, Bunaea alcinoe, Gonimbrasia cocaulti, Gonimbrasia belina, Gynanisa nigra and Cirina forda. Two morphotypes of G. zambesina and B. alcinoe were recorded. These saturniid caterpillars occur twice a year except for G. cocaulti. Predictive models revealed that tropical and subtropical regions were potentially suitable for B. alcinoe and C. forda. The information generated from this study would be important to guide conservation efforts and their sustainable utilization as food in Africa.

Keywords: Bunaea alcinoe; Cirina forda; Gonimbrasia zambesina; Gonimbrasia belina; saturniids; edible insects; entomophagy; edible caterpillars; host plants 


\section{Introduction}

The Food and Agriculture Organization of the United Nations has termed edible insects as one of the solutions to curb food insecurity [1]. Edible insects have been described as an alternative protein source [2] and recent studies have shown that they are a rich source of antioxidants [3] and are beneficial to the human gut microbiota [4]. Production of these insects is more sustainable compared to livestock since they require less land area [5], they offer a more efficient feed conversion [2] and emit less greenhouse gases [6]. Furthermore, edible insects require less water for mass production [7] and have the potential to be reared on bio-waste [8,9], which could in turn lower the cost of production.

Globally, more than 2 billion people consume over 2000 species of edible insects [2,10]. About $60 \%$ of edible insect species in Africa belong to the order Lepidoptera which includes edible saturniids [11]. Saturniids occur widely across Africa, USA, Australia and Asia [12-14]. Edible saturniids availability and consumption has been documented in West $[15,16]$, Central [17] and southern Africa [18-20]. However, knowledge on the species diversity and edible saturniids consumed in East Africa is scarce. Most studies on edible saturniid caterpillars concentrated on western and southern Africa [21].

Edible saturniids are characterized by big larval forms with spines on the surface which pupate into cocoons [22] that are formed on the plants or leaf litters in the ground from which brightly colored moths emerge [12-14,23]. The most economically important saturniid that is consumed widely in southern Africa is the mopane worm, Gonimbrasia belina (Westwood). The larvae of Go. belina is an important food commodity among rural communities that live around the mopane woodland, i.e., the mopane belt across Angola, Zambia, Zimbabwe Mozambique, South Africa and Botswana [24]. They have been commercialized and contribute considerably to the rural economies; for instance, in Limpopo, South Africa, $63 \%$ of the harvested worms are sold in the local markets [20]. Another edible saturniid larvae in Africa with high commercial value is the pallid emperor moth or shea defoliator, Cirina forda (Westwood). Its larvae are considered an important food source for many rural communities in Zimbabwe, Nigeria, Togo, Ghana, Zambia, D.R. Congo, Central African Republic, and South Africa [16,25,26].

Edible saturniid species have been observed to inhabit different bioecological zones with considerable seasonal variability, as well as having high specificity and preference to various host plants. For example, in southern and eastern Africa, they are known to occur in large outbreaks in arid and savannah regions [12,14,27]. Edible saturniids can either be bivoltine or univoltine depending on the region $[16,17,23,28-30]$. Larvae of the mopane worm have been observed to feed specifically on Colophospermum mopane Kirk ex J. Léonard (Fabaceae) [31] while, C. forda show higher preference for the shea butter tree, Vittelaria paradoxa C.F. Gaertn (Sapotaceae) in West Africa [32,33].

Edible saturniid caterpillars are highly nutritious, providing vital vitamins, lipids and proteins and microelements to households, especially women and children $[3,18,34-36]$. Despite being highly nutritious, the diversity of edible saturniid caterpillars has not been studied in Kenya. Semi-wild rearing of edible saturniid caterpillars could promote proper land use management and forest conservation in an agroforestry setting [37]. The scarcity of information on edible saturniids and their distribution and host plants in Kenya has hampered the prospects of promoting their sustainable access and consumption as food among communities in Kenya. Knowledge on the host plants and the distribution of saturniids in Kenya may also promote their conservation in the ecosystem. The information on the host plants could open new opportunities for their mass production to ensure continuous supply. Therefore, the aim of the present study was to establish the diversity, distribution, and host plants of edible saturniids in Kenya. Further habitat suitability maps were also generated for selected saturniid species to assess their distribution under present and future climate change scenarios. 


\section{Materials and Methods}

\subsection{Study Area}

The study was carried out between March 2017 and May 2019 across different agroecological zones [38,39] and altitudes in Kenya. The highland areas (1200-2000 m above sea level (meters above sea level, m.a.s.l.)) included Nakuru, Laikipia, Tharaka Nithi, Embu, Meru, and Nairobi counties, while the lowlands areas (0-750 m.a.s.l.) were represented by the counties of Makueni, Taita, Kwale and Kilifi. The middle altitude areas (750-1200 m.a.s.l.) included Homabay, Kitui, Kajiado and Machakos counties (Table S1). Some additional samples collected from Ibadan, Nigeria and Tutume, Botswana alone were included for comparison with samples collected in Kenya.

\subsection{Sample Collection and Preparation}

Saturniid larvae were sampled at random along motorable roads from 15 sites (Table 1 ) in Kenya. Mostly fourth and fifth instar stages were collected, placed in buckets with twigs from their host plant and transported to icipe, Nairobi, Kenya, for rearing and identification. Twigs of host plants were collected and pressed in a herbarium for identification. Sampling was done for five rainy seasons between March 2017 and May 2019, both long (March to May) and short rains (October-December), in Kenya.

Table 1. Morphological characteristics of saturniids collected in Kenya.

\begin{tabular}{|c|c|c|c|c|}
\hline \multirow[b]{2}{*}{ Species } & \multicolumn{4}{|c|}{ Characteristics } \\
\hline & Moth Color & $\begin{array}{l}\text { Hindwing Eyespot Description } \\
\text { (Innermost to Outermost Color) }\end{array}$ & Mature Larvae Color & $\begin{array}{l}\text { 5th Instar Spine } \\
\text { Color }\end{array}$ \\
\hline Gonimbrasia zambesina & Green & $\begin{array}{l}\text { Greenish-yellow center, black, } \\
\text { greenish-yellow, white rings }\end{array}$ & $\begin{array}{l}\text { Black with grey and } \\
\text { yellow speckles }\end{array}$ & Black or red \\
\hline Gonimbrasia zambesina & Brown & $\begin{array}{l}\text { Yellowish brown center, black, pink, } \\
\text { white rings }\end{array}$ & $\begin{array}{l}\text { Black with grey and } \\
\text { yellow speckles }\end{array}$ & Red \\
\hline Gonimbrasia cocaulti & Brown & $\begin{array}{l}\text { White center, reddish, black and } \\
\text { white rings }\end{array}$ & Black with whitish speckles & Yellow \\
\hline Gonimbrasia krucki & Yellow & Yellow center, black, pink, red rings & $\begin{array}{l}\text { Black with greenish-yellow } \\
\text { speckles and orange spots } \\
\text { on spiracles }\end{array}$ & Black \\
\hline Cirina forda & Light Brown & Small with a black ring & Black with yellow bands & White \\
\hline Gonimbrasia belina & $\begin{array}{l}\text { Reddish- } \\
\text { Brown }\end{array}$ & Brown center, black, white rings & $\begin{array}{l}\text { Black with red, grey and } \\
\text { green speckles }\end{array}$ & Black \\
\hline Bunaea alcinoe & Dark brown & Orange center, black, white rings & $\begin{array}{l}\text { Black with orange spots } \\
\text { on spiracles }\end{array}$ & White/yellow \\
\hline Bunaea alcinoe & - & - & Red & White \\
\hline Gynanisa nigra & - & - & Green with white speckles & White \\
\hline Gonimbrasia belina & - & - & $\begin{array}{l}\text { Black with red, grey and } \\
\text { greenish speckles }\end{array}$ & Black \\
\hline
\end{tabular}

'-' Means moths were not collected.

Field-collected Saturniid larvae were reared at $12 \mathrm{~h}: 12 \mathrm{~h}$ photoperiod at $25{ }^{\circ} \mathrm{C}$ in Perspex cages $(50 \times 50 \times 50 \mathrm{~cm})$ with nets on the sides for ventilation. Cages were protected from ants and crawling insects with traps containing water placed below its metallic stand. The saturniid larvae were fed on twigs of their respective host plant from the field. The twigs were placed in a container as bouquet with stem immersed in water fastened by wet cotton wool. The twigs were changed daily to keep them fresh. The larvae fed until they reached the pre-pupal stage, when they stopped feeding, reduced movement, and moved to the floor of the cage ready to burrow and pupate. The pre-pupae were placed on moist sterile sawdust in plastic trays and allowed to burrow into the sawdust to pupate as they burrow in soil in the wild. The saw dust was kept moist by sprinkling water daily. The trays with the pupae were placed in Perspex cages $(50 \mathrm{~cm} \times 50 \mathrm{~cm} \times 50 \mathrm{~cm})$ awaiting emergence of adult moths. 


\subsection{Morphological Identification}

The adult moths were killed by placing them in a container and freezing them at $-5{ }^{\circ} \mathrm{C}$. They were stretched out, pinned, allowed to dry, and labeled before morphological identification. Identification was carried out using published keys [12] and crosschecked with reference voucher specimens at National Museums of Kenya (NMK) collection and pictures from available literature [40,41] by Mr. Alex Musyoki, Mr Ashikoye Okoko and Dr. Esther Kioko, NMK. Voucher specimens are deposited at the Biosystematics Unit, icipe. Host plants were identified at the Kenya Forest Research Institute (KEFRI) by an experienced plant taxonomist using available literature [42].

\subsection{Molecular Identification}

\subsubsection{Tissue Preparation, DNA Extraction and Quantification}

Leaf samples of each host plant of saturniid caterpillar were carefully washed with tap water, rinsed with distilled water and dried with paper towel. They were then cut into $0.2 \mathrm{~g}$ of leaf sample small pieces with a sterile blade and placed in a $2 \mathrm{~mL}$ tube containing ceramic beads, lysis buffer PA1 (Bioline, London, UK) and RNAse A and crushed for 3 min in a Tissue lyser II (Qiagen, Germantown, MD, USA). Plant genomic DNA was extracted using Isolate II Plant DNA extraction Kit (Bioline, London, UK) as per the manufacturer's instructions.

A leg of each adult moth and/or a portion of larvae collected were cut with a sterile blade and placed in a $2 \mathrm{~mL}$ tube. Insect genomic DNA was extracted using Isolate II genomic DNA extraction kit (Bioline, London, UK) as per the manufacturer's protocol. The resultant DNA was eluted in $50 \mu \mathrm{L}$ Elution buffer (Bioline, London, UK) and quantified using a NanoDrop 2000/2000 c spectrophotometer (Thermo Fisher Scientific, Wilmington, NC, USA). Insect and plant DNA samples were stored at $-20^{\circ} \mathrm{C}$ for further downstream processing.

\subsubsection{PCR for Insect Samples}

For insect identification, PCR was conducted using general insect DNA barcoding LepF1/LepR1 primers (LEP F1-5' ATTCAACCAATCATAAAGATATTGG 3'; LEP R1 $5^{\prime}$ TAAACTTCTGGATGTCCAAAAAATCA $3^{\prime}$ ) [43]. Isolated insect DNA was amplified in $30 \mu \mathrm{L}$ PCR mix containing 17.025 $\mu \mathrm{L}$ PCR water, $6 \mu \mathrm{L}$ My Taq Buffer (Bioline, London, UK), (5 mM dNTPs, $15 \mathrm{mM} \mathrm{MgCl}$, stabilizers and enhancers), $1.5 \mu \mathrm{L}$ of each primer, $0.6 \mu \mathrm{L}$ of $25 \mathrm{mM} \mathrm{MgCl} 2$ (Thermo Fisher Scientific, Waltham, MA, USA), $0.375 \mu \mathrm{L} 1$ unit My Taq DNA polymerase (Bioline, London, UK) and $15 \mathrm{ng} / \mathrm{L}$ of DNA template. The reaction was set up in a Mastercycler Nexus Gradient thermocycler (Thermo Fisher Scientific, Waltham, MA, USA) using conditions as follows: initial denaturation at $95^{\circ} \mathrm{C}$ for $2 \mathrm{~min}$ followed by 40 cycles of denaturation at $95^{\circ} \mathrm{C}$ for $30 \mathrm{~s}$, annealing at $52{ }^{\circ} \mathrm{C}$ for $40 \mathrm{~s}$ and primer elongation at $72{ }^{\circ} \mathrm{C}$ for $1 \mathrm{~min}$. The final extension step lasted for $10 \mathrm{~min}$ at $72{ }^{\circ} \mathrm{C}$.

\subsubsection{PCR for Plant Samples}

General plant primers 3F_KIM_F/1R_KIM_R (3F_KIM_F 5' CGTACAGTACTTTTGTGTTTACGAG $3^{\prime}$; 1R_KIM_R5 ${ }^{\prime}$ ACCCAGTCCATCTGGAAATCTTGGTTC $3^{\prime}$ ) were used to amplify a $900 \mathrm{bp}$ region of the matK gene for the identification of host plants. Protocols for PCR of plant samples were similar to the PCR protocol for insect samples (Section 2.4.2), except the annealing step which was done at $49^{\circ} \mathrm{C}$ for $45 \mathrm{~s}$.

\subsubsection{Agarose Gel Electrophoresis, PCR Product Purification and Sequencing}

Resolution of the PCR product was done with $1 \%$ agarose gel stained with ethidium bromide (10 mg/mL) at 80 volts for $1 \mathrm{~h}$ (Bio-Rad model 200/2-0 power supply, Bio-Rad laboratories Inc., Hercules, CA, USA). DNA bands were visualized using an ultraviolet transilluminator and photographed using the KETA GL imaging system software (Wealtec Corp., Sparks, NV, USA). The resultant PCR products for both the insects and the host plants were purified using QIAquick PCR purification kit (Qiagen, Hilden, Germany) and 
quantified with a NanoDrop 2000/2000 c spectrophotometer (Thermo Fisher Scientific, Wilmington, NC, USA) before being sent for bidirectional sequencing at Macrogen Inc. (Amsterdam, The Netherlands).

\subsubsection{Sequence Analysis}

Both plant and insect sequences were assembled and edited using Bioedit software v. 7.0.5.2 [44]. A consensus sequence generated from both the forward and reverse strand was queried on Basic Local Alignment Search Tool (BLAST) [45] and Barcode Of Life Data system (BOLD) [46] to determine similarity with sequences in the database. The default Species level barcode records were used. The top published hit on Bold was used for identification. Multiple sequence alignments were created on Clustal W [47]. Pairwise distances were generated using using Mega X [48]. Sequences were submitted to the GenBank (https:/ /www.ncbi.nlm.nih.gov/WebSub/) (accessed on 10 March 2020) (see Table S2).

\subsection{Distribution Modelling}

Two species of edible saturniids were selected for distribution modeling, i.e., B. alcinoe and C. forda, because of their popularity and economic importance in sub-Saharan Africa (SSA). Cirina forda and B. alcinoe are widely consumed [11,17,49-51] and traded [16,52-54] in western, central, eastern, and southern Africa.

\subsubsection{Occurrence Data}

The occurrence data (species name, GPS co-ordinates) for the two species was collected during field surveys in Kenya and from the Global Biodiversity Information Facility (GBIF). A total of 96 points (Figure 1a) were acquired (59 from field surveys and 37 from GBIF) for B. alcinoe, while the $C$. forda dataset comprised 70 points ( 57 from field surveys and 13 from GBIF) (Figure 1b).
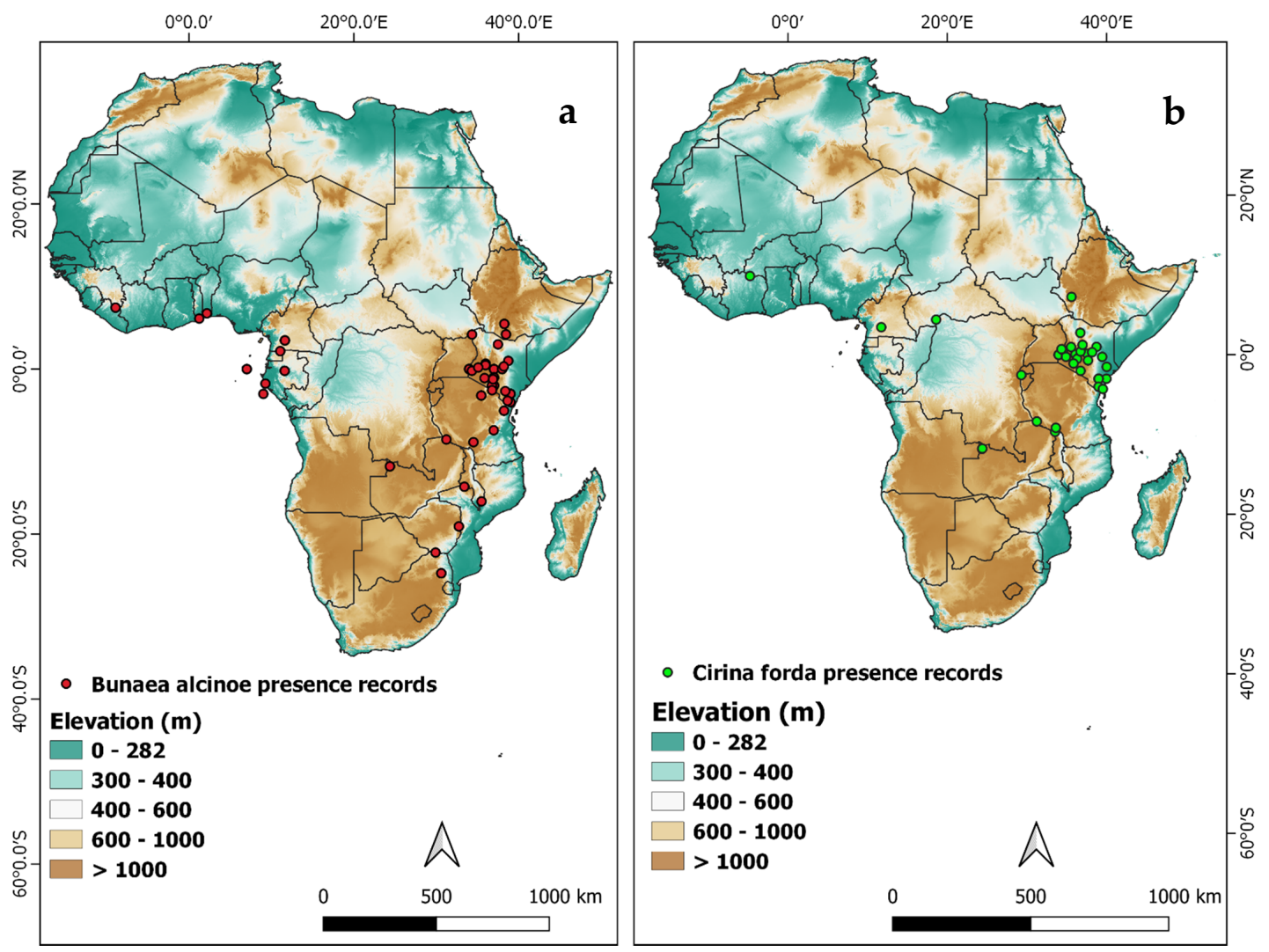

Figure 1. Geographical distribution records of (a) Bunaea alcinoe and (b) Cirina forda in Africa. 


\subsubsection{Environmental Variables}

Nineteen bioclimatic variables downloaded from WorldClim (www.worldclim.org) (accessed on 15 April 2021) were considered for the study. We obtained current climate data for the period 1970-2000 at 30 arc seconds longitude/latitude degree spatial resolution (approximately $1 \mathrm{~km}$ at the equator). For future analysis, the downscaled and calibrated horizon 2050 IPPC (CMIP5) of climate projection bioclimatic variables were extracted from HadGEM2-ES global climate model (GCM) representing representative concentration pathways (RCP8.5) for future climate scenarios set by the intergovernmental panel on climate change (IPCC) [53]. RCP8.5 scenario predicts the mean global temperature increase projections of up to $3.7^{\circ} \mathrm{C}$. A collinearity test was conducted on the 19 bioclimatic variables to reduce collinearity between variables, to avoid overfitting of the model and variable inflation [54]. The variance inflation factor (VIF) test was used to assess the correlation between variables. The "vifcor" function in R software version 3.0.1 was used to run the VIF test [55]. Six bioclimatic variables, namely Bio2 (mean diurnal temperature range), Bio3 (Isothermality), Bio5 (max temp of warmest month), Bio13 (precipitation of wettest month), Bio15 (precipitation seasonality), and Bio19 (precipitation of coldest quarter) were selected for the B. alcinoe species analysis, while seven bioclimatic variables namely, Bio2, Bio4 (temperature seasonality), Bio8 (mean temperature of wettest quarter), Bio13, Bio15, Bio18 (precipitation of warmest quarter), and Bio19 were selected for the C. forda species analysis using a cutoff of $|\mathrm{r} 2|>0.7$. Aside from the spatial correlation, the ecological relevance of the variables was also considered.

\subsubsection{Model Calibration and Accuracy Assessment}

Ecological niches of the two species were modeled using Maximum Entropy (MaxEnt) in the MaxEnt tool package version 3.4.1k which performs well for modeling presence only data [55]. The ENMEval package in R software was used to determine the required parameter settings to be used in Maxent software for the optimum tuning of the models [56]. Following the parameter settings from ENMEvaluate, three features (linear, quadratic and hinge) were utilized with a regularization multiplier of 3 . The model calibration created the optimal models for the two saturniid species. The models were replicated 3 times using cross-validation method and an ensemble of the three probability outputs were used to determine the optimum suitability and performance of the models. Seventy percent of the presence records were utilized to train the model while $30 \%$ of the points were used to validate the performance of the model. The comparative relevance of each environmental variable for the models of $C$. ford $a$ and B. alcinoe was evaluated using the overall percentage contribution, area under the curve (AUC), and the Jackknife test. AUC values of 0 indicate impossible occurrence area while 1 indicates optimal occurrence area. The ROC method has shown to be effective in evaluating model performance and being independent of prevalence $[57,58]$. Outputs of the models highlighting the intensity and extent of habitat suitability of the two species were mapped with values ranging from 0 (unsuitable) to 1 (optimum). Suitability levels were grouped into five categories as follows: very low (0-0.1), low (0.1-0.3), moderate (0.3-0.5), high (0.5-0.7), and very high (0.7-1).

\section{Results}

\subsection{Morphological Identification of Edible Saturniids}

Seven species of Saturniidae were identified in Kenya. They include B. alcinoe, C. forda, Gonimbrasia zambesina (Walker), Go. cocaulti Darge and Terral, Go. belina Westwood, Go. krucki (Hering) and Gynanisa nigra Bouvier. Dead larval stages of Gonimbrasia belina collected from Botswana and a sample of B. alcinoe collected from Nigeria were included for comparison (Table 1).

\subsubsection{Bunaea alcinoe}

Larvae are black with orange spots on the spiracles along the sides of the body. One $B$. alcinoe larva collected from Nigeria is red in color. Larvae of both color forms of B. alcinoe 
have white/yellow spines (Figure 2). Bunaea alcinoe moths are dark brown in color with a large glass spot on the forewing (Table 1). The hind wing has an orange eyespot ringed with black followed by white (Figure 3).
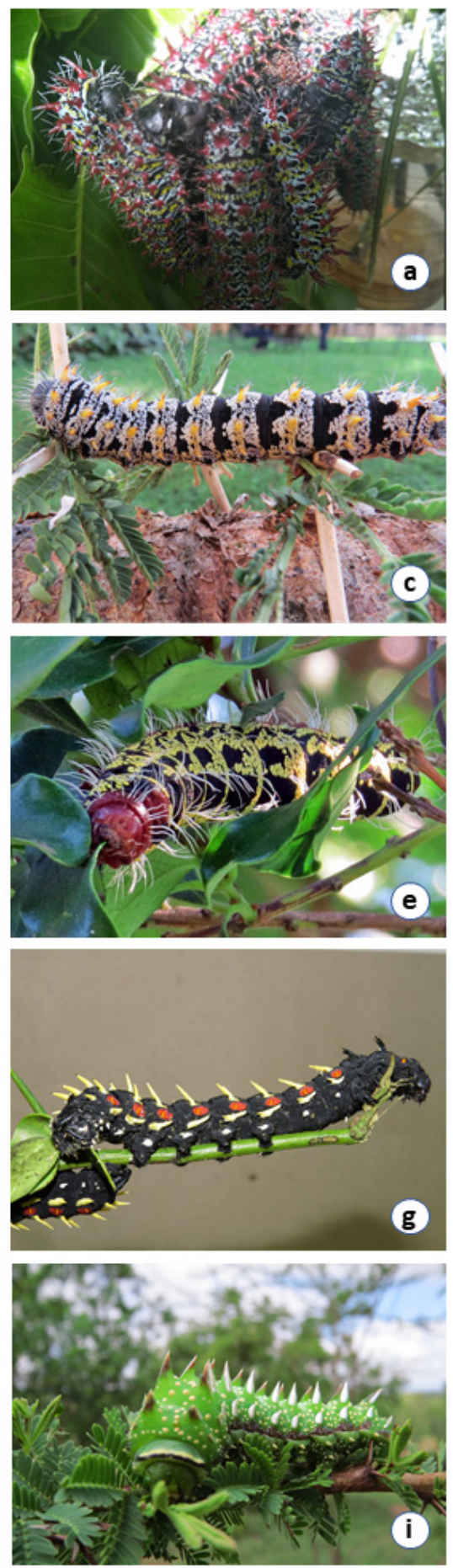
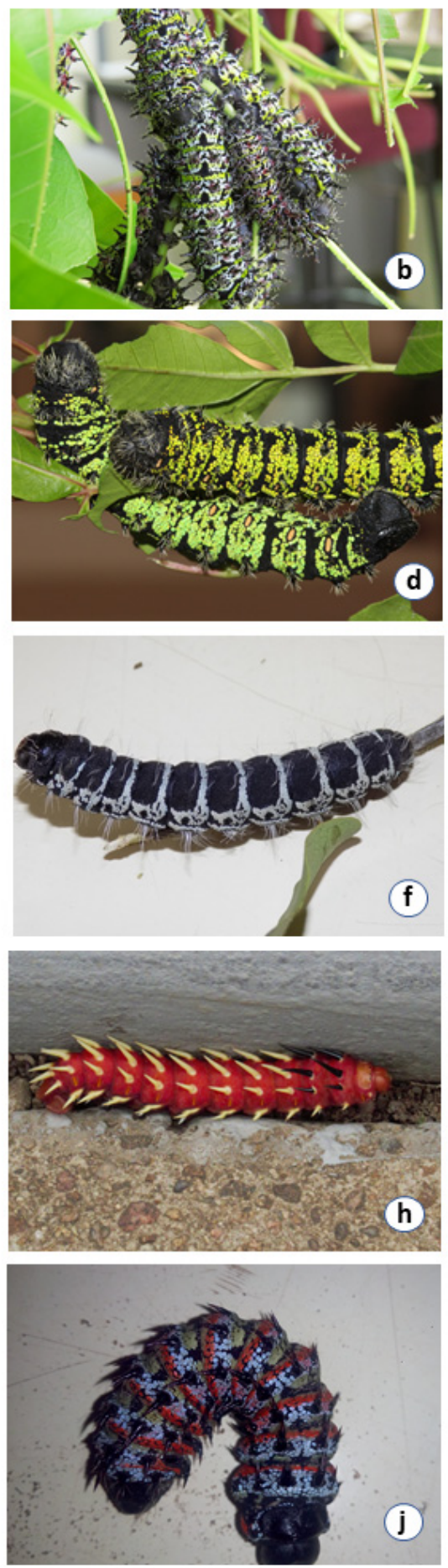

Figure 2. Pictures of saturniid larvae. (a) Gonimbrasia zambesina larvae with red spines, (b) Gonimbrasia zambesina larvae with black spines, (c) Gonimbrasia cocaulti, (d) two color forms of Gonimbrasia krucki larvae; black with green speckles and black with yellow speckles, (e) Cirina forda larva black in color with yellow spots, (f) Cirina forda larva black in color with white spots, (g) Bunaea alcinoe black form observed in East Africa, (h) Bunaea alcinoe red form observed in West Africa, (i) Gynanisa nigra larvae, (j) Gonimbrasia belina collected in Kenya. 

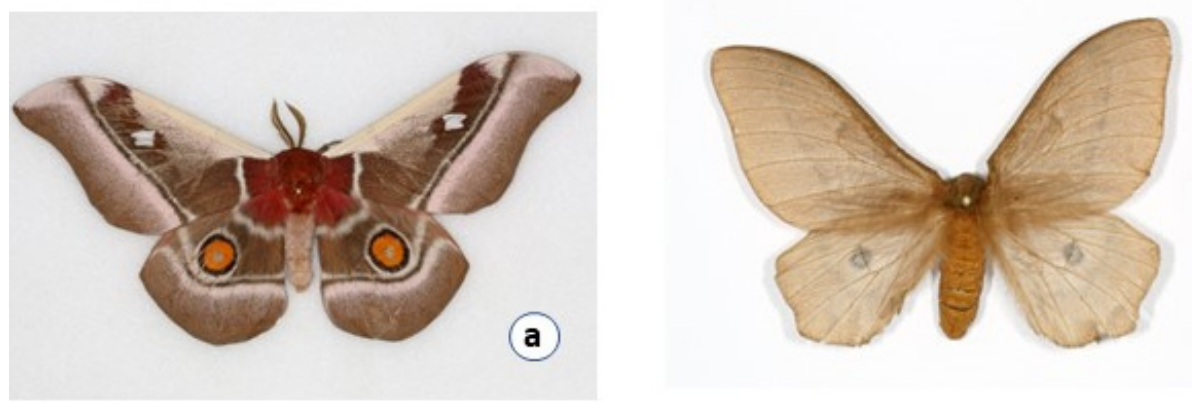

(b)
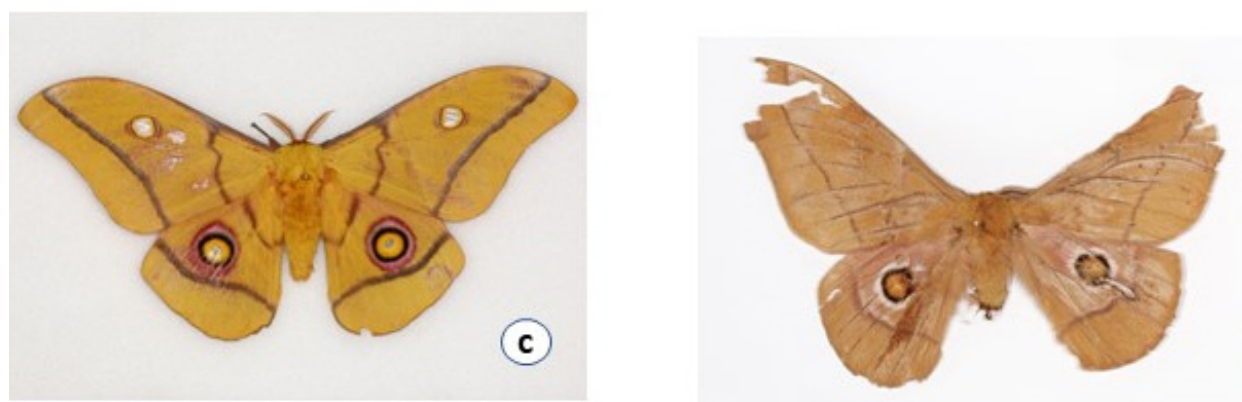

(d)
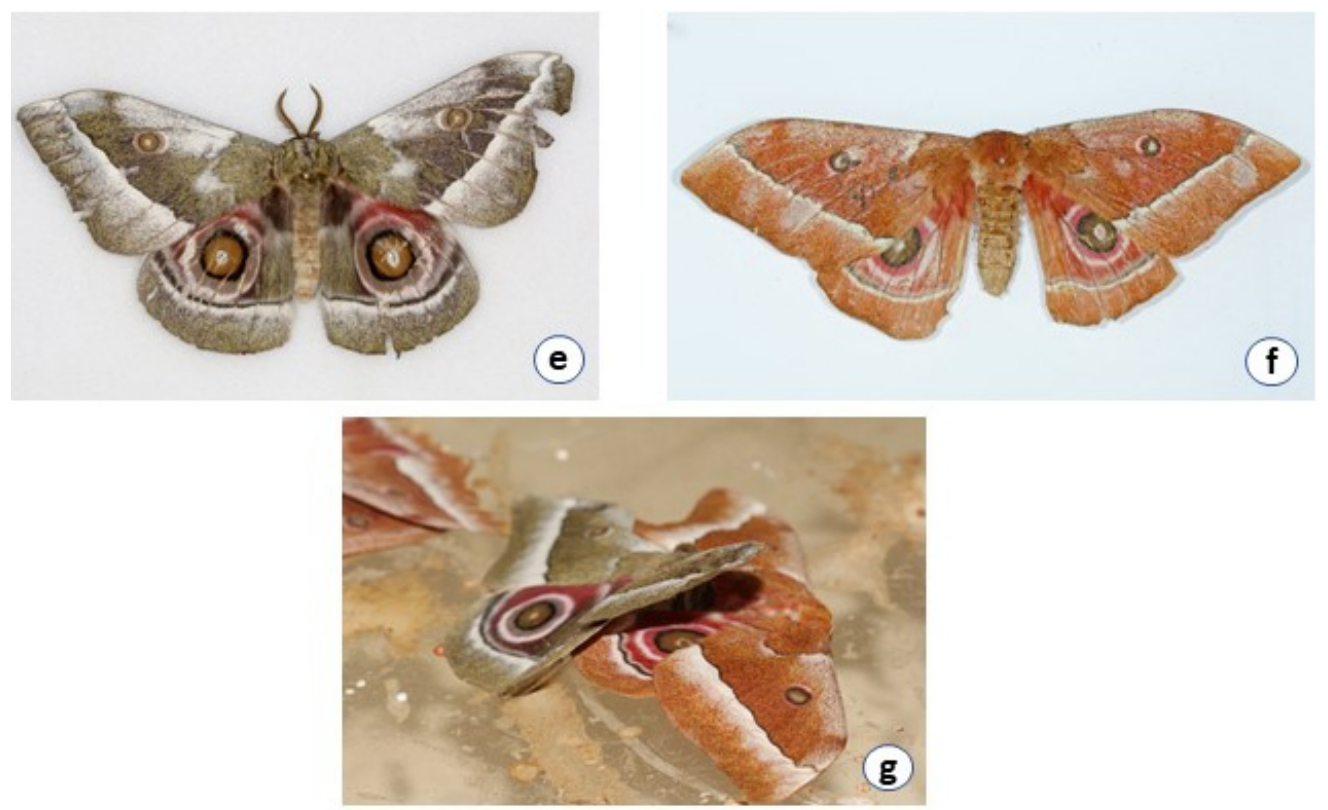

Figure 3. Pictures of saturniid moths. (a) Bunaea alcinoe, (b) Cirina forda, (c) Gonimbrasia krucki, (d) Gonimbrasia belina, (e) green form of Gonimbrasia zambesina, (f) brown form of Gonimbrasia zambesina, (g) mating pair of brown and green form of G. zambesina.

\subsubsection{Cirina forda}

Larvae are black with yellow bands and white hairy spines. Cirina forda moths are smaller than the other moths. Cirina forda larvae in the same colony also presented in two color forms. Some had a black body with yellow bands while others had a black body with white bands (Figure 2). It is light brown in color with a small black eyespot on the hindwing (Table 1, Figures 2 and 3).

\subsubsection{Gonimbrasia cocaulti}

Larvae appear black with whitish speckles and yellow spines. Cirina forda moths are smaller than the other moths. It is light brown in color with a small black eyespot on the hindwing (Figure 3). Gonimbrasia cocaulti moths have a brownish ground color 
with eyespots on both the forewing and hindwing. The eyespot on the hindwing is white surrounded by reddish, black, and white rings while the one on the forewing is whitish circled by a brownish and white ring (Table 1, Figures 2 and 3).

\subsubsection{Gonimbrasia krucki}

Larvae are black with greenish-yellow speckles and black thick spines. Gonimbrasia krucki presented two color forms of their larvae. Larvae produced from the same egg clutch developed into forms that had a black body with either yellow or green speckles (Figure 2). Gonimbrasia krucki moths have a yellow ground color with defined eyespots on both the forewing and the hindwing. Both eyespots are yellow in color ringed with black, pink, and red (Figure 3).

\subsubsection{Gonimbrasia belina}

Larvae are red, grey, and green with black spines. Gonimbrasia belina moths are reddish brown in color with a brown eyespot on the hind wing circled by black and white rings. It has a small glass spot on the forewing. The front part of the hindwing is reddish in color (Figures 2 and 3).

\subsubsection{Gonimbrasia zambesina}

Larvae are black with yellow and grey speckles while some have black spines and others red spines (Table 1, Figure 2). Gonimbrasia zambesina moths occur in two color forms, green and brown. The green form is reddish purplish on the forward part of the hindwing. The eyespot on the hindwing is greenish yellow in the middle, circled by a black ring followed by greenish-yellow and white. The brown form has a yellowish-brown eyespot on the hind wing with black, pink, and whitish rings (Figure 3). The brown form is not available in the NMK collection. The dichotomous key [12] reported the specimen as Go. said (Oberthuer). However, the author expressed uncertainty and suggested that it could be a form of G. zambesina. The green forms were collected from Kilifi, Embu and Kwale, while a mixture of the green and brown forms was collected from Makuyu in Murang'a County (all Kenyan sites). The green moths from Kwale and Kilifi produced larvae that were black with grey and yellow speckles and black spines (Figure 2). Green moths from Embu laid eggs that hatched into larvae that were black with grey and yellow speckles and with red spines. The green and brown moths were also observed to mate with each other. The brown and green moths collected in Makuyu mated among themselves (green and green/green and brown/brown and brown) to produce black larvae with grey and yellow speckles and with red spines (Figure 3).

\subsubsection{Gynanisa nigra}

Larvae of Gy. nigra are green with white speckles and white spines (Figure 2). We could not get adult moth from field collected Gy. nigra due to extensive parasitism.

\subsection{Molecular Identification}

All the saturniid species showed $98.22-100 \%$ similarity to sequences in BOLD. Gonimbrasia belina collected in Kenya and Gy. nigra were 100\% similar to sequence GBMNC60703-20 (Go. belina; BIN-BOLD:AAB6786) and GBMNC60687-20 (Gy. Nigra; BIN- BOLD:AED6623), respectively. Gonimbrasia zambesina sequences were 99.09-100\% similar to SAPBA77307 (Go. Zambesina; BIN-BOLD:AAD1339)) while Go. krucki was 98.22-100\% similar to SAPBA635-07 (Go. Krucki; BIN-BOLD:AAD8374)). Cirina forda had 99.38-99.85\% similarity to SATWA281-07 (C. forda; BIN-BOLD:AAB6982) and STBOB620-08 (C. forda; BIN-BOLD:AAB6982). Gonimbrasia cocaulti sequences were $>98 \%$ similar to SPBIS152-09 (Go. Cocaulti; BIN-BOLD:AEH8028). Bunaea alcinoe sequences from samples collected in Kenya were 98.78-100\% similar to LSAFR2238-12 from South Africa (B. alcinoe; BINBOLD:AAA6757) (Table 2). 
Table 2. Identities of saturniids based on similarities with sequences from BOLD.

\begin{tabular}{|c|c|c|c|c|}
\hline Collection Site & $\begin{array}{l}\text { Sample } \\
\text { Code }\end{array}$ & Species & $\begin{array}{c}\% \text { Similarity to } \\
\text { BOLD Sequences }\end{array}$ & $\begin{array}{c}\text { Sequence ID of Similar Sequences-Top } \\
\text { Published Hit with Default BOLD Query } \\
\text { (Collection Site) }\end{array}$ \\
\hline Mwingi, Kenya & S30 & Go. cocaulti & 98.88 & SPBIS152-09 (Kenya) \\
\hline Taita, Kenya & S34 & Go. cocaulti & 98.88 & SPBIS152-09 (Kenya) \\
\hline Matuu, Kenya & S22 & Go. cocaulti & 98.72 & SPBIS152-09 (Kenya) \\
\hline Taita, Kenya & S32 & Go. cocaulti & 98.87 & SPBIS152-09 (Kenya) \\
\hline Taita, Kenya & S33 & Go. cocaulti & 98.88 & SPBIS152-09 (Kenya) \\
\hline Matuu, Kenya & S28 & Go. cocaulti & 98.72 & SPBIS152-09 (Kenya) \\
\hline Muhaka, Kenya & S48 & Go. belina & 100 & GBMNC60703-20 (Kenya) \\
\hline Ibadan, Nigeria & Nigeria-1 & B. alcinoe & 100 & SATWA891-07 (Burkina-Faso) \\
\hline Matuu, Kenya & S84 & B. alcinoe & 99.24 & LSAFR2238-12 (South Africa) \\
\hline Matuu, Kenya & S85 & B. alcinoe & 99.39 & LSAFR2238-12 (South Africa) \\
\hline Nanyuki, Kenya & S87 & B. alcinoe & 99.24 & LSAFR2238-12 (South Africa) \\
\hline Nanyuki, Kenya & S88 & B. alcinoe & 99.24 & LSAFR2238-12 (South Africa) \\
\hline Mbita, Kenya & S90 & B. alcinoe & 99.39 & LSAFR2238-12 (South Africa) \\
\hline Mbita, Kenya & S91 & B. alcinoe & 99.08 & LSAFR2238-12 (South Africa) \\
\hline Embu, Kenya & S92 & B. alcinoe & 99.23 & LSAFR2238-12 (South Africa) \\
\hline Embu, Kenya & S93 & B. alcinoe & 98.78 & LSAFR2238-12 (South Africa) \\
\hline Nairobi, Kenya & $\mathrm{S} 2$ & Go. krucki & 100 & SAPBA635-07 (Kenya) \\
\hline Nairobi, Kenya & S3 & Go. krucki & 100 & SAPBA635-07 (Kenya) \\
\hline Mbita, Kenya & S6 & C. forda & 99.54 & SATWA281-07 (Cameroon) \\
\hline Mbita, Kenya & S7 & C. forda & 99.54 & SATWA281-07 (Cameroon) \\
\hline Kilifi, Kenya & S55 & C. forda & 99.41 & STBOB620-08 (Malawi) \\
\hline Ngong, Kenya & $2 \mathrm{CF}$ & C. forda & 99.38 & STBOB620-08 (Malawi) \\
\hline Ngong, Kenya & $5 \mathrm{CF}$ & C. forda & 99.69 & STBOB620-08 (Malawi) \\
\hline Gilgil, Kenya & S54 & C. forda & 99.85 & STBOB620-08 (Malawi) \\
\hline Kilifi, Kenya & S17 & Go. zambesina & 100 & SAPBA773-07 (Kenya) \\
\hline Kilifi, Kenya & S18 & Go. zambesina & 100 & SAPBA773-07 (Kenya) \\
\hline Kambiti, Kenya & S79 & Go. zambesina & 99.54 & SAPBA773-07 (Kenya) \\
\hline Kambiti, Kenya & S94 & Go. zambesina & 99.39 & SAPBA773-07 (Kenya) \\
\hline Embu, Kenya & S95 & Go. zambesina & 99.39 & SAPBA773-07 (Kenya) \\
\hline Embu, Kenya & S96 & Go. zambesina & 99.58 & SAPBA773-07 (Kenya) \\
\hline Makuyu, Kenya & S97 Brown & Go. zambesina & 99.54 & SAPBA773-07 (Kenya) \\
\hline Makuyu, Kenya & S98 Brown & Go. zambesina & 99.54 & SAPBA773-07 (Kenya) \\
\hline Makuyu, Kenya & S99 Green & Go. zambesina & 99.54 & SAPBA773-07 (Kenya) \\
\hline Makuyu, Kenya & S100 Green & Go. zambesina & 99.09 & SAPBA773-07 (Kenya) \\
\hline Makuyu, Kenya & S101 Green & Go. zambesina & 99.39 & SAPBA773-07 (Kenya) \\
\hline Makuyu, Kenya & S102 Green & Go. zambesina & 99.39 & SAPBA773-07 (Kenya) \\
\hline Makuyu, Kenya & S104 Brown & Go. zambesina & 99.39 & SAPBA773-07 (Kenya) \\
\hline Makuyu, Kenya & S105 Brown & Go. zambesina & 99.54 & SAPBA773-07 (Kenya) \\
\hline Makuyu, Kenya & S107 Brown & Go. zambesina & 99.24 & SAPBA773-07 (Kenya) \\
\hline Botswana & IBB-1 & Go. belina & 99.84 & SATWA003-06 (Zambia) \\
\hline Botswana & IBB-2 & Go. belina & 99.85 & SATWA003-06 (Zambia) \\
\hline Kenya & GMB-2 & Gy. nigra & 100 & GBMNC60687-20 (Botswana) \\
\hline Botswana & GM-1 & Gy. westwoodi & 99.69 & STBOA580-07 (Kenya) \\
\hline Botswana & GM-2 & Gy. westwoodi & 99.69 & STBOA580-07 (Kenya) \\
\hline
\end{tabular}

Gynanisa westwoodi and G. belina collected from Botswana were both $>99 \%$ similar to STBOA580-07 (BIN-BOLD: ABY462) and SATWA003-06 (BIN-BOLD: AAB6786), respectively. Bunaea alcinoe sequences from sample collected in Nigeria was 100\% similar to SATWA891-07 (B. alcinoe; BIN-BOLD: AAA6756) (Table 2).

Gonimbrasia krucki and B. alcinoe-Nigeria species had a 100\% similarity to sequences from BOLD database. Gonimbrasia zambesina had a within species pairwise distance range of $0-0.61$ and a range of $0-0.91$ between species and BOLD sequence SAPBA773-07 (BOLD:AAD1339) (Table 3). Gonimbrasia belina collected in Botswana and Gynanisa westwoodi had a $100 \%$ similarity within species, while they had a pairwise distance range of 0.15-0.16 and 0.3 with BOLD sequences SATWA003-06 (BOLD:AAB6786) and STBOA580- 
07 (BOLD:ABY4629), respectively (Table 3). Gonimbrasia belina collected in Kenya was 100\% similar to the BOLD sequence, while G. nigra had a pairwise distance of 0.61. Cirina forda showed a pairwise distance range of $0.3-2.13$ within species and $0.46-2.13$ between species and BOLD sequence SATWA281-07 (BOLD:AAB6982) (Table 3).

Table 3. Genetic p-distance comparisons for saturniid species.

\begin{tabular}{|c|c|c|c|}
\hline Insect Species (Sample Size) & $\begin{array}{l}\text { Genetic p-Distance Range } \\
\text { within Sample Species }\end{array}$ & $\begin{array}{l}\text { BOLD Sequence Used for } \\
\text { Comparison (BOLD BIN } \\
\text { Cluster Number) }\end{array}$ & $\begin{array}{c}\text { Genetic p-Distance Range } \\
\text { between Sample Species and } \\
\text { BOLD Sequence }\end{array}$ \\
\hline Gonimbrasia zambesina (15) & $0-0.61$ & $\begin{array}{c}\text { SAPBA773-07 } \\
\text { (BOLD:AAD1339) }\end{array}$ & $0-0.91$ \\
\hline Gonimbrasia krucki (2) & 0.0 & $\begin{array}{l}\text { SAPBA635-07 } \\
\text { (BOLD:AAD8374) }\end{array}$ & 0.0 \\
\hline Gonimbrasia belina-Kenya (1) & 0.0 & $\begin{array}{l}\text { GBMNC60703-20 } \\
\text { (BOLD:AAB6786) }\end{array}$ & 0.0 \\
\hline Gonimbrasia cocaulti (7) & $0-1.52$ & SPBIS152-09 (BOLD:AEH8028) & $1.42-2.88$ \\
\hline Gonimbrasia belina-Botswana (2) & 0.0 & $\begin{array}{l}\text { SATWA003-06 } \\
\text { (BOLD:AAB6786) }\end{array}$ & $0.15-0.16$ \\
\hline Cirina forda (4) & $0.3-2.13$ & $\begin{array}{l}\text { SATWA281-07 } \\
\text { (BOLD:AAB6982) }\end{array}$ & $0.46-2.13$ \\
\hline Bunaea alcinoe-Kenya (8) & $0-1.52$ & $\begin{array}{l}\text { LSAFR2238-12 } \\
\text { (BOLD:AAA6757) }\end{array}$ & $0.61-1.98$ \\
\hline Bunaea alcinoe-Nigeria (1) & 0.0 & $\begin{array}{l}\text { SATWA891-07 } \\
\text { (BOLD:AAA6756) }\end{array}$ & 0.0 \\
\hline Gynanisa nigra (1) & 0.0 & $\begin{array}{c}\text { STBOC836-08 } \\
\text { (BOLD:AED6623) }\end{array}$ & 0.61 \\
\hline Gynanisa westwoodi (2) & 0.0 & $\begin{array}{l}\text { STBOA580-07 } \\
\text { (BOLD:ABY4629) }\end{array}$ & 0.3 \\
\hline
\end{tabular}

Molecular Differences among the Color Forms of Gonimbrasia zambesina and Bunaea alcinoe

Although Go. zambesina larvae and moths depicted different color forms morphologically, they identified as the same species using molecular characteristics. The genetic distance between all the Go. zambesina samples and the reference Go. zambesina sequence from BOLD (SAPBA773-07; BIN BOLD:AAD1339) was 0-0.61\% while the genetic distance between all the samples and Go. zambesina sequence from BOLD (SAPBA772-07) was $1.07-1.23 \%$. The genetic distance between the samples was $0-0.61 \%$. All the samples included in the analysis had 658 bp (Figure 4).

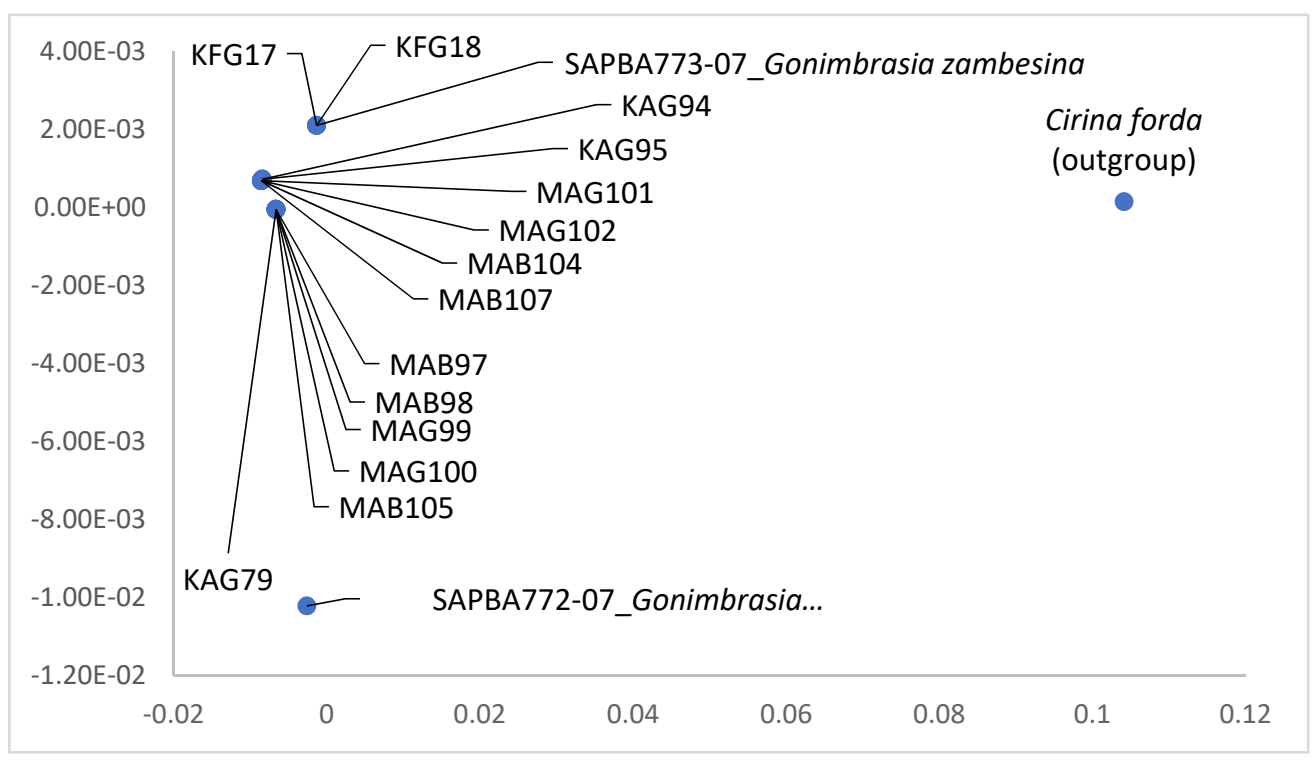

Figure 4. Principle coordinate analysis of COI gene of different morphotypes of Gonimbrasia zambesina from different locations in Kenya. The first two letters indicate the collection sites (MA = Makuyu, $\mathrm{KA}=\mathrm{Kambiti}$, and $\mathrm{KF}=\mathrm{Kilifi})$. The last letter indicates the color of the adult moth $(\mathrm{G}=$ green and $\mathrm{B}=$ brown). The number indicates sample ID. SAPBA772-07 and SAPBA773-07 are BOLD reference accession numbers in BOLD BIN cluster BOLD:AAD1339. 
The morphological difference of the two larvae color forms of B. alcinoe was also supported by molecular characterization. The red form with white spines (Nigeria-1) was 100\% similar to SATWA891-07-COI-5P (B. alcinoe; BIN BOLD:AAA6756) from Burkina Faso. However, the same BOLD sequence had a $3.28-3.76 \%$ genetic distance from all the other black larvae forms of B. alcinoe collected from Kenya (see Table S4. All the other black forms with white spines from Kenya showed a genetic distance of $0.61-0.76 \%$ from LSAFR2238-12 (B. alcinoe; BIN BOLD:AAA6757) from South Africa. The same BOLD sequence had a genetic distance of $3.76 \%$ from the red color form collected from Nigeria. All the black forms clustered together with LSAFR2238-12 (B. alcinoe) while the red form clustered with SATWA891-07-COI-5P (B. alcinoe). All the samples included in the analysis had $658 \mathrm{bp}$ (Figure 5).

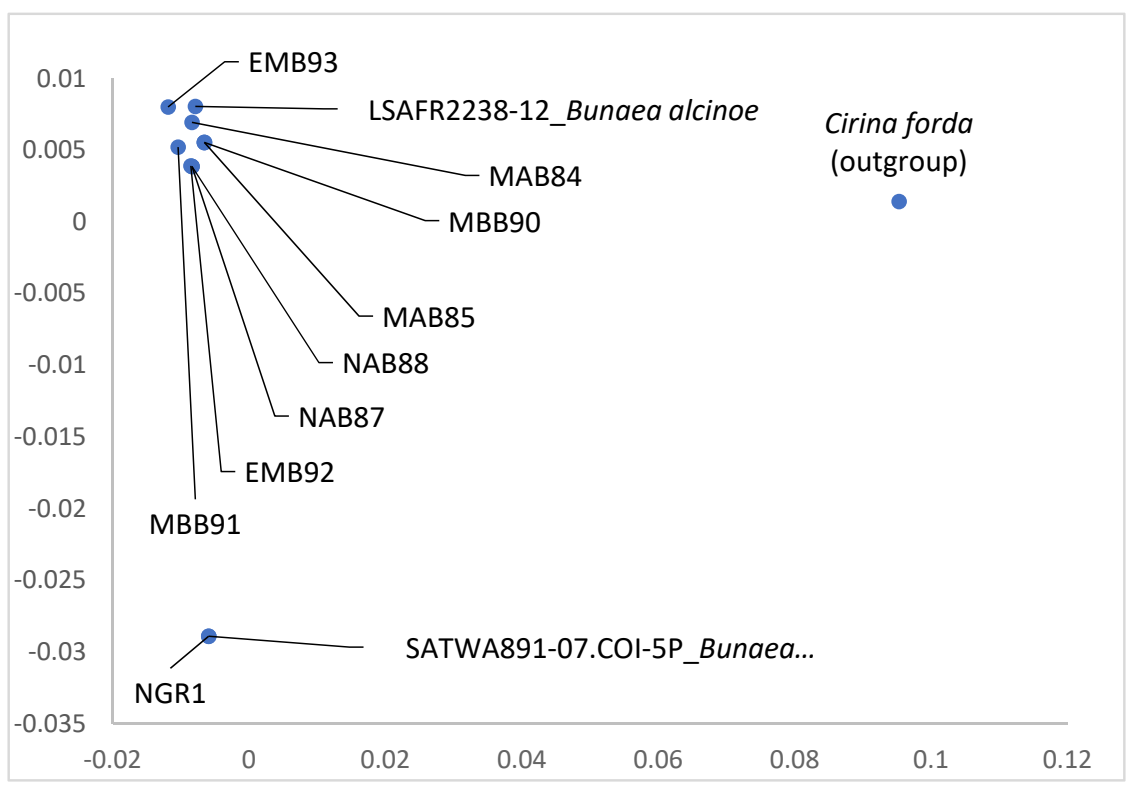

Figure 5. The principle coordinate analysis of COI gene of morphotypes of Bunaea alcinoe from Kenya and Nigeria. The first two letters indicate the collection sites (NG = Nigeria, MB = Mbita, $\mathrm{EM}=\mathrm{Embu}, \mathrm{NA}=$ Nanyuki and MA = Matuu). The last letter depicts the color of the larvae $(\mathrm{R}=$ red and $\mathrm{B}=$ black). The number indicates sample ID. SATWA891-07.COI-5P (BIN BOLD:AAA6756) and LSAFR2238-12 (BIN BOLD:AAA6757) are BOLD reference accession numbers.

\subsection{Distribution and Seasonality of Edible Saturniids in Kenya}

The distribution of the edible saturniids in the various Counties in Kenyan is presented in Table S1. Gonimbrasia zambesina, C. forda, Go. krucki, and B. alcinoe were bivoltine occurring between April-June and October-December, reflecting the major and minor rainy seasons in the region. On the other hand, Go. cocaulti was univoltine and occurred only during the April-June season (Table 4). The distribution of these saturniids was attributed to the availability of their host plants. The most widespread saturniid was $B$. alcinoe while the least widespread were Go. belina and Go. krucki which were only found in Kwale and Nairobi, respectively (Table 4).

Table 4. Seasonality and distribution of edible saturniids in Kenya.

\begin{tabular}{cccc}
\hline Saturniid & Place Found & April-June & October-December \\
\hline Gonimbrasia zambesina & Kilifi, Embu, Machakos, Kwale, Murang'a & Present & Present \\
Cirina forda & Kilifi, Nakuru, Embu, HomaBay, Kajiado & Present & Present \\
Gonimbrasia cocaulti & Taita, Makueni, Machakos, Kitui, Isiolo & Present & Absent \\
Bunaea alcinoe & Machakos, Makueni, Homabay, Meru, Kitui, Embu, Laikipia & Present & Present \\
Gonimbrasia krucki & Nairobi & Present & Present \\
Gonimbrasia belina & Kwale & Present & Present \\
\hline
\end{tabular}




\subsection{Habitat Suitability and Probability Distribution}

3.4.1. Area under Curve (AUC) Values

All the models using the current and future (RCP8.5:2050) showed a balance between goodness-of-fit and complexity (AUC $>0.80$ ), for all the test and training datasets (Table 5). This demonstrates that our models showed good predictive performance.

Table 5. Area under curve values for training and test data.

\begin{tabular}{ccccc}
\hline \multirow{2}{*}{ Species } & \multicolumn{2}{c}{ Current } & \multicolumn{2}{c}{ RCP8.5 } \\
\cline { 2 - 5 } & Training & Test & Training & Test \\
\hline Bunaea alcinoe & 0.855 & 0.915 & 0.877 & 0.928 \\
Cirina forda & 0.850 & 0.867 & 0.876 & 0.860 \\
\hline
\end{tabular}

\subsubsection{Visualization of Habitat Suitability under Current and Future Climatic Conditions}

Habitat suitability maps show that the tropics are optimal for both B. alcinoe (Figure 6) and C. forda (Figure 7). Parts of the subtropical region in southern Africa are marginally suitable for B. alcinoe. For both MaxENT and GARP maps, a slight reduction in habitat suitability for both saturniids is predicted in future climate scenarios. Northern Africa is unsuitable in both present and future scenarios for B. alcinoe and C. forda.
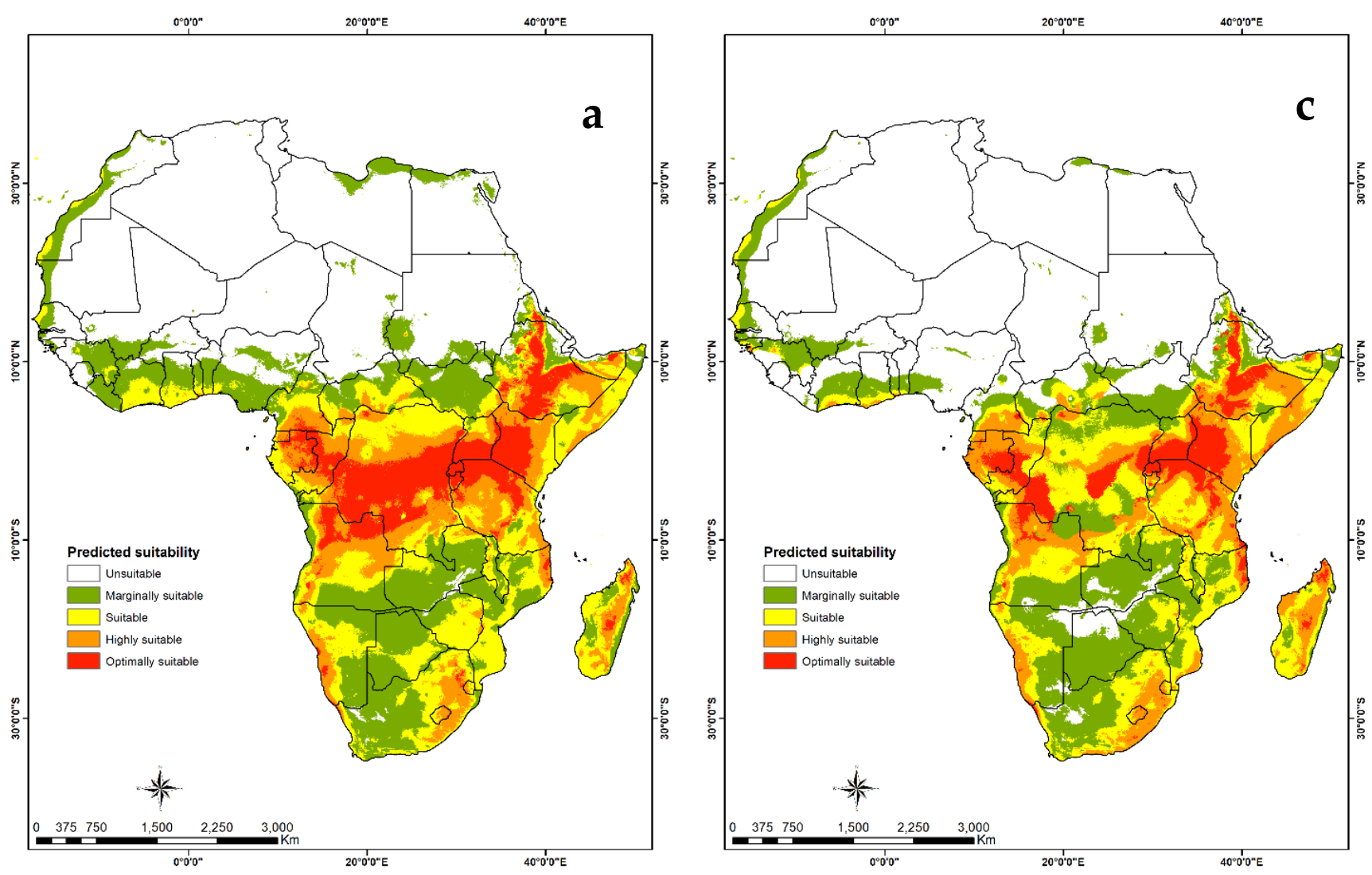

Figure 6. Cont. 

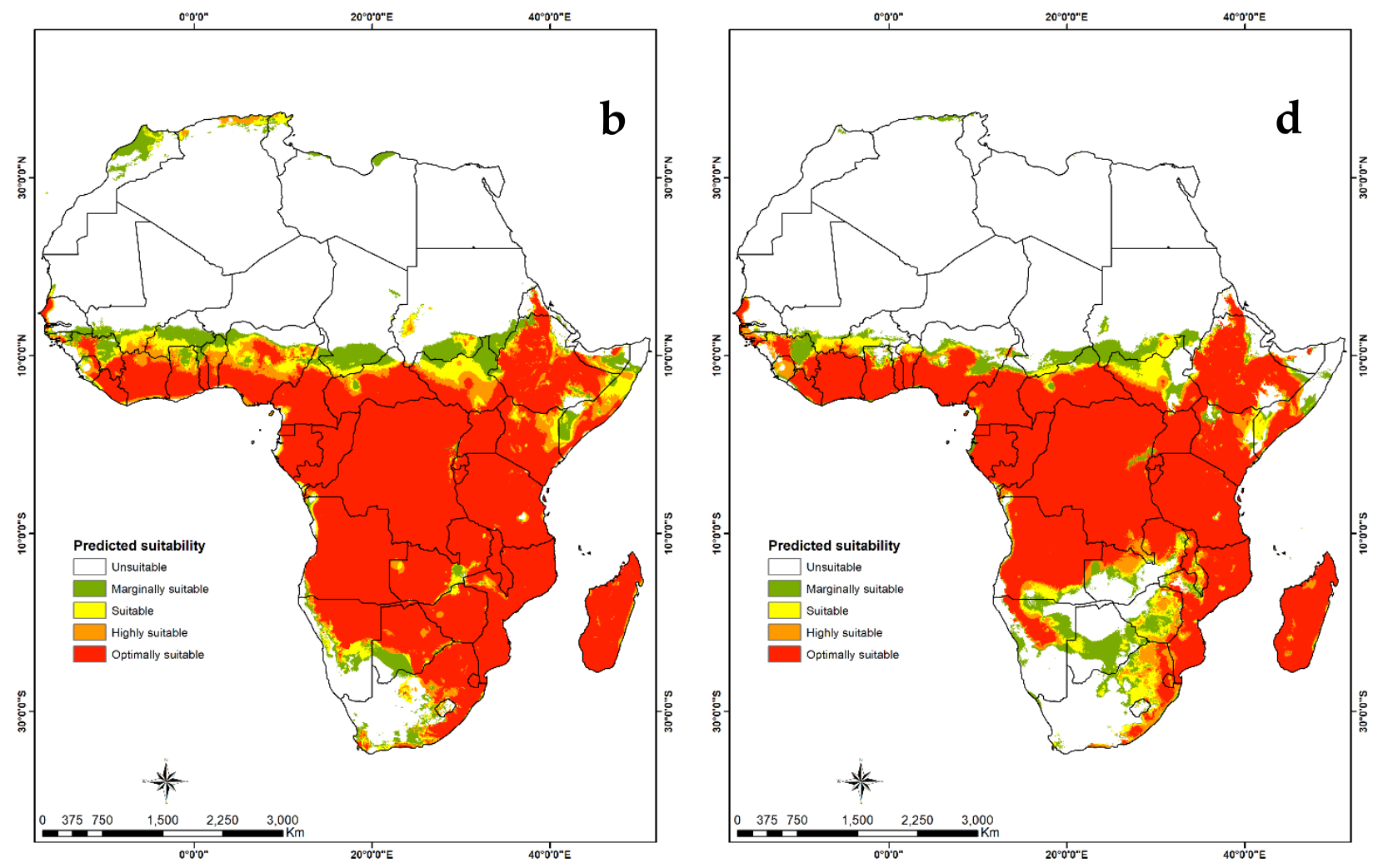

Figure 6. Predictive suitability map of the geographic distribution of Bunaea alcinoe. (a) Suitability map generated by the MaxEnt algorithm under current climate scenario; (b) suitability map generated by the GARP algorithm under current climatic scenario; (c) suitability map generated by MaxEnt algorithm under future climatic scenarios and (d) suitability map generated by the GARP algorithm under future climatic scenarios.
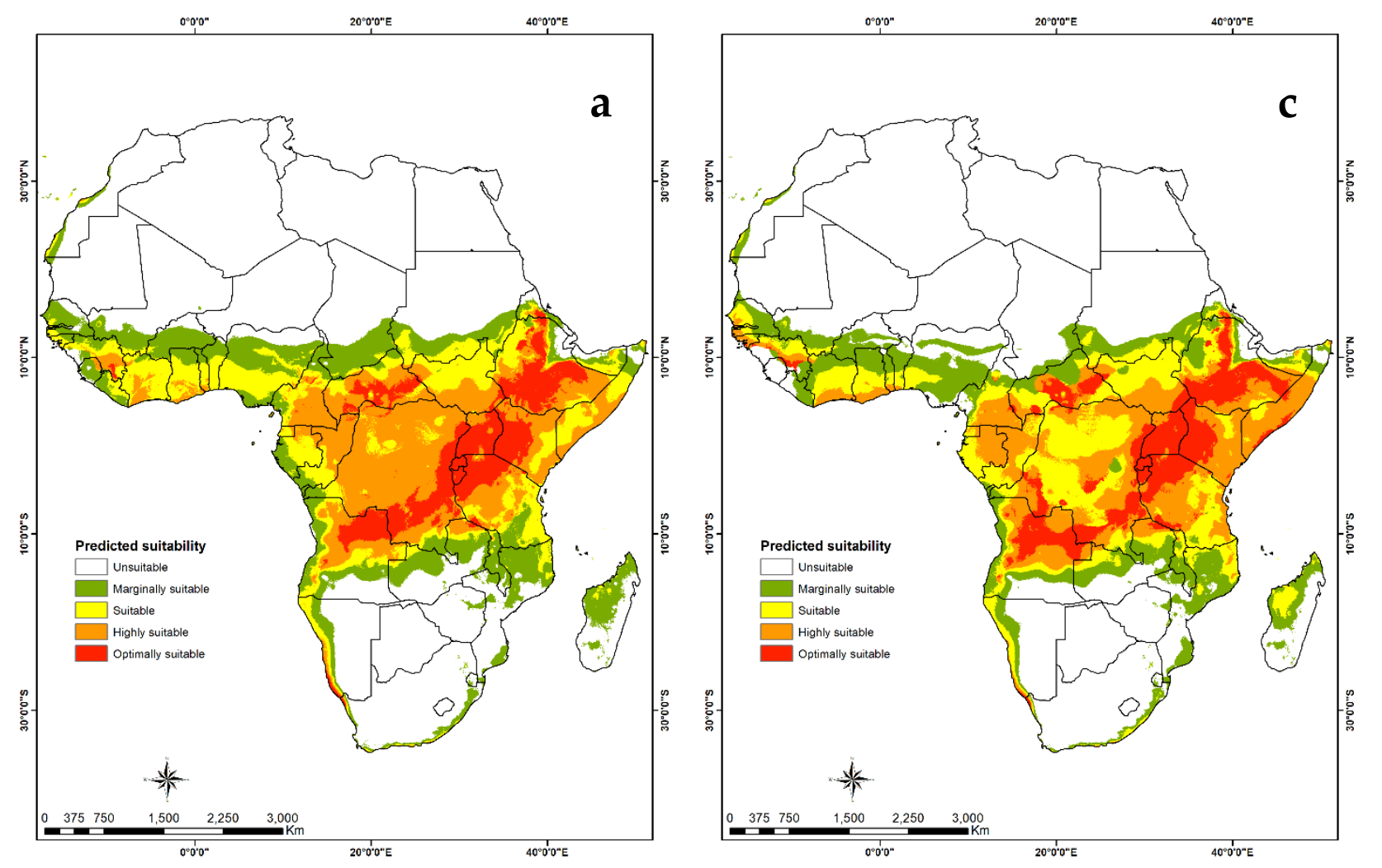

Figure 7. Cont. 

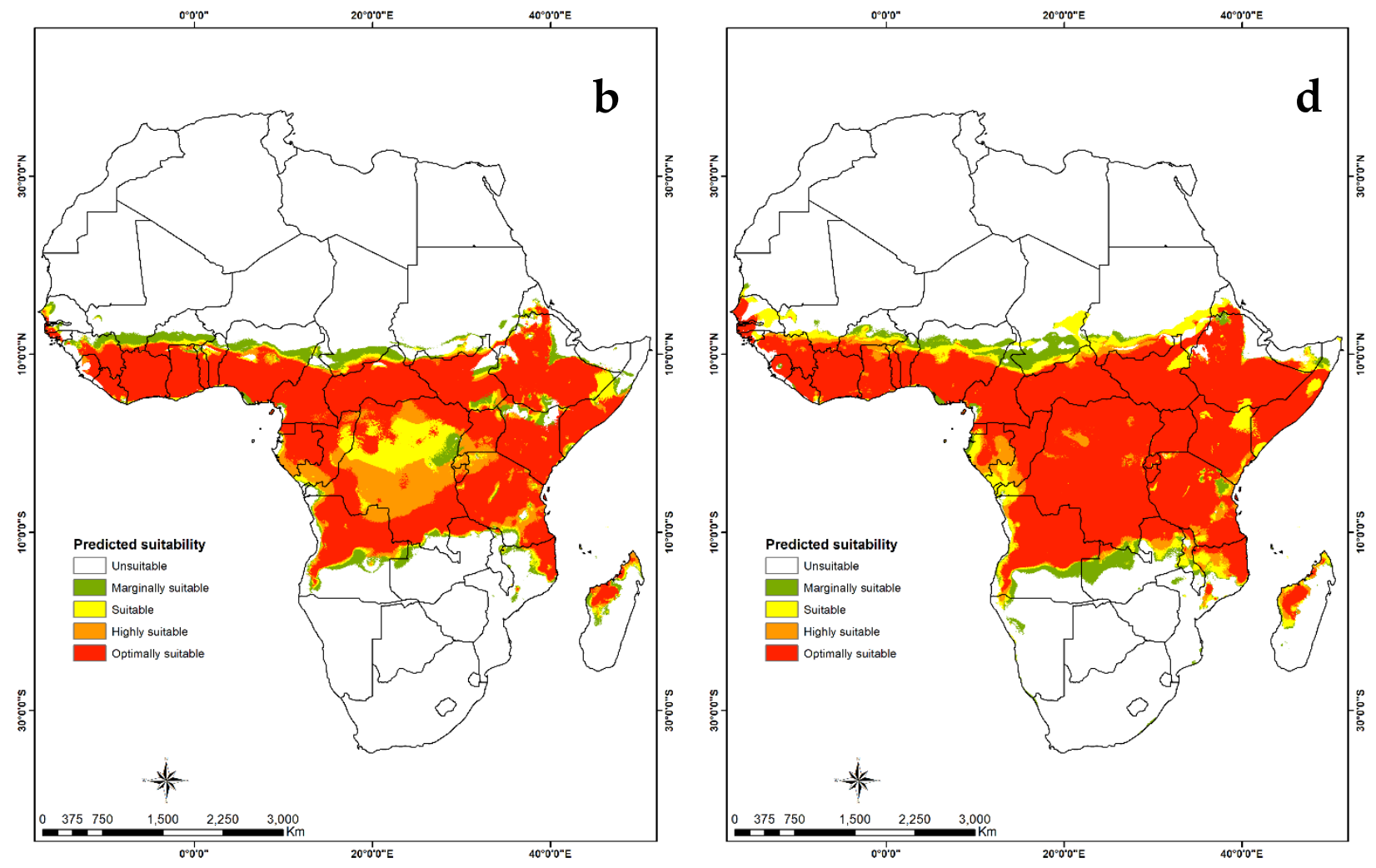

Figure 7. Predictive suitability map of the geographic distribution of Cirina forda. (a) Suitability map generated by the MaxEnt algorithm under current climate scenario; (b) suitability map generated by the GARP algorithm under current climatic scenario; (c) suitability map generated by MaxEnt algorithm under future climatic scenarios and (d) suitability map generated by the GARP algorithm under future climatic scenarios.

\subsection{Host Plants of Edible Saturniids in Kenya}

The caterpillars were observed to show very distinct host plant specificity across the various sites surveyed. We observed that Go. cocaulti and B. alcinoe mainly feed on Vachellia nilotica (L.) P.J.H. Hurter and Mabb (Fabaceae), while B. alcinoe was feeding on Balanites aegyptiaca Linn (Zygophyllaceae) and Balanites glabra Mildbr. and Schltr. (Zygophyllaceae). Gonimbrasia cocaulti also fed on Vachellia tortilis (Forssk.) Galasso and Banfi (Fabaceae), while Go. zambesina and Go. belina on Anacardium occidentale Lin (Anacardiaceae) and Go. zambesina as well on Mangifera indica L. (Anacardiaceae). Gonimbrasia krucki was only observed feeding on Schinus terebinthifolia Raddi and Schinus molle L. (Anacardiaceae) while C. forda seemed to have a broader host range with Euclea divinorum, Acacia mearrnsii De Wild (Fabaceae) and Manilkara sulcata Engl. (Sapotaceae) (Table 6).

Table 6. Host plants consumed by edible saturniids in Kenya.

\begin{tabular}{cc}
\hline Saturniid & Host Plant \\
\hline Gonimbrasia zambesina & Mangifera indica, Anacardium occidentale \\
Cirina forda & Euclea divinorum, Acacia mearnsii, Manilkara sulcata \\
Gonimbrasia cocaulti & Vachellia tortilis, Vachellia nilotica \\
Bunaea alcinoe & Balanites aegyptiaca, Balanites glabra \\
Gonimbrasia krucki & Schinus terebinthifolia, Schinus molle \\
Gonimbrasia belina & Anacardium occidentale \\
\hline
\end{tabular}

In terms of genetic analyses, E. divinorum, A. occidentale, $M$. indica, Balanites sp., $V$. tortilis, Manilkara sp., A. mearnsii, S. terebinthifolia and V. nilotica had a $97.06-100 \%$ similarity to GenBank sequences (Table 7). 
Table 7. Identities of edible saturniid host plants based on similarities with sequences from GenBank.

\begin{tabular}{|c|c|c|c|c|}
\hline Collection Site & Sample Code & Species & $\begin{array}{c}\% \text { Similarity to } \\
\text { GenBank Sequences }\end{array}$ & $\begin{array}{l}\text { ID of Similar } \\
\text { Sequences }\end{array}$ \\
\hline Gilgil, Nakuru & HP7 & Euclea divinorum & 100 & DQ924074.1 \\
\hline Mbita, Homabay & HP17 & Euclea divinorum & 97.06 & DQ924074.1 \\
\hline Mbita, Homabay & HP18 & Euclea divinorum & 98.11 & DQ̄924074.1 \\
\hline Gilgil, Nakuru & HP37 & Euclea divinorum & 99.64 & DQ924074.1 \\
\hline Embu & HР38 & Euclea divinorum & 99.76 & DQ̄924074.1 \\
\hline Gilgil, Nakuru & HР39 & Euclea divinorum & 100 & DQ924074.1 \\
\hline Embu & HP40 & Euclea divinorum & 99.76 & DQ924074.1 \\
\hline Matuu, Machakos & HP21 & Vachellia tortilis & 99.54 & AF274140.1 \\
\hline Taita & $\mathrm{HP} 22$ & Vachellia tortilis & 99.77 & AF274140.1 \\
\hline Makueni & HP23 & Vachellia tortilis & 99.77 & AF274140.1 \\
\hline Mwingi & $\mathrm{HP} 24$ & Vachellia tortilis & 99.88 & AF274140.1 \\
\hline Ngong, Kajiado & HP25 & Acacia mearnsii & 99.88 & НМ020723.1 \\
\hline Ngong, Kajiado & HP26 & Acacia mearnsii & 99.76 & HM020723.1 \\
\hline Ngong, Kajiado & HP27 & Acacia mearnsii & 100 & НМ020723.1 \\
\hline Ngong, Kajiado & HP28 & Acacia mearnsii & 100 & HM020723.1 \\
\hline Kilifi, Malindi & HP16 & Manilkara sp. & 99.40 & DQ924092.1 \\
\hline Kilifi, Malindi & HP33 & Manilkara sp. & 99.40 & DQ924092.1 \\
\hline Kilifi, Malindi & HP36 & Manilkara sp. & 99.40 & DQ924092.1 \\
\hline Muhaka, Kwale & HP11 & Anacardium occidentale & 100 & KY 635877.1 \\
\hline Malindi, Kilifi & HP10 & Mangifera indica & 100 & KX871231.1 \\
\hline Mbita, Homabay & HP3 & Balanites sp. & 99.35 & JX517722.1 \\
\hline Mbita, Homabay & HP32 & Balanites sp. & 99.22 & JX517722.1 \\
\hline Matuu, Machakos & HP45 & Balanites sp. & 99.48 & JX517722.1 \\
\hline Matuu, Machakos & HP46 & Balanites sp. & 99.48 & JX517722.1 \\
\hline Nanyuki & $\mathrm{HP} 47$ & Balanites sp. & 99.48 & JX517722.1 \\
\hline Embu & $\mathrm{HP} 48$ & Balanites sp. & 99.48 & JX517722.1 \\
\hline Embu & HP45 & Balanites sp. & 99.48 & JX517722.1 \\
\hline Matuu, Machakos & $\mathrm{HP} 2$ & Vachelia nilotica & 99.30 & KY10024.1 \\
\hline Buruburu, Nairobi & $\mathrm{HP} 49$ & Schinus terebinthifolia & 100 & KP149521.1 \\
\hline Buruburu, Nairobi & HP51 & Schinus terebinthifolia & 100 & KP149521.1 \\
\hline Kasarani, Nairobi & HP63 & Schinus terebinthifolia & 100 & KP149521.1 \\
\hline Kasarani, Nairobi & HP62 & Schinus terebinthifolia & 100 & KP149521.1 \\
\hline Kasarani, Nairobi & HP60 & Schinus terebinthifolia & 99.53 & KP149521.1 \\
\hline Kasarani, Nairobi & HP61 & Schinus terebinthifolia & 99.53 & KP149521.1 \\
\hline Kasarani, Nairobi & HP58 & Schinus terebinthifolia & 99.41 & KP149521.1 \\
\hline
\end{tabular}

\section{Discussion}

This study has documented seven species of edible saturniids in Kenya. Three saturniid species, i.e., C. forda, Go. zambesina and B. alcinoe, are consumed in Kenya, mainly along the coastal belt along the Giriama community. Moreover, $C$. forda is widely consumed in West, Central and southern Africa [15,16,33,51]. Bunaea alcinoe is also a popular edible insect in West and Central Africa, for instance in countries like DR Congo, Cameroon and Nigeria [59-61], while Go. zambesina is highly popular in southern and Central Africa [17,59,62]. Gonimbrasia krucki is widely consumed in DR Congo [17], but not in Kenya. For Go. cocaulti, no records of human consumption are available from Kenya or elsewhere in Africa. However, due to the similarity of Go. cocaulti larva to that Go. belina, it is likely misidentified, given that they have been observed in consignments of mopane caterpillar in the UK [63].

Bunaea alcinoe, though black in colour and commonly found in Kenya, its genetic configuration is different from the red forms collected in Nigeria [64]. In Nigeria and DR Congo, both color forms have been reported feeding on the same host plant $[17,64]$, yet this is the first time their genetic difference has been assessed. Further detailed studies relating the morphological and molecular differences, mating compatibility between color forms of B. alcinoe can shed light on their taxonomic status. 
The sampled G. zambesina moths also exhibited two color forms and juveniles of the green adults carried black spines, as previously reported [12] and in http:/ /www. africanmoths.com/ (accessed on 26 September 2019) [41]. The brown moths emerged from red spined larvae, which had been previously described as G. said [12], but inconclusively. Identification of edible saturniid species is important for the purpose of conservation [37,65], maintenance of quality in production [63] as well as mainstreaming consumption of the caterpillars.

We observed a bivoltine lifecycle in C. forda, with larvae occurring in April-June and October-December. In contrast, $C$. forda has been recorded as univoltine in Togo and Nigeria with larval occurrence between July and September $[16,29]$ and in DR Congo with larvae appearing between November and January [17]. In all these cases, the occurrence of $C$. forda larvae coincides with the rainy seasons. For, B. alcinoe we noted a bivoltine lifecycle with larval appearance between April-May and October-December. In contrast, the same species in DR Congo is univoltine and occurs between October and May [17]. Understanding the temporal distribution of edible saturniids informs the need for mass production to ensure a continuous source throughout the year.

The model for habitat suitability of B. alcinoe and C. forda demonstrates that the two species thrive well within the tropical regions of Africa. However, $B$ alcinoe spreads slightly into the subtropics, specifically in southern Africa. The model concurs with previous reports of availability and consumption of the two edible saturniids in southern, central and western Africa $[11,16,17,28,33,51,59,66]$. However, the availability of $C$. forda in the southern African region is not concurrent with previous reports [14,23] which recorded a wide distribution in the southern Africa region. This could be due to the limited data on the presence of the two saturniid species in the GBIF database which was used in this study. Future predictions for both species show a slight reduction in habitat suitability, stressing the need to conserve edible saturniid species' habitats.

The saturniids identified fed on specific host plants and consequently their availability depends on the occurrence of these host plants. We found B. alcinoe feeding on B. aegyptiaca and B. glabra similar to reports in Nigeria [63]. However, other research suggests a wide range of host plants, e.g., for DR Congo with Sarcocephalus latifolius (JE Sm.) EA Bruce (Rubiaceae), Acacia auriculiformis A. Cunn. ex Benth. (Fabaceae), Dacryodes edulis (G. Don) H.J.Lam. (Burseraceae), Crossopteryx febrifuga (Afzel. ex G.Don) Benth. (Rubiaceae) and Anthocleista schweinfurthii Gilg (Loganiaceae) [13], and in Nigeria on Holarrhena floribunda (G. Don) Durand and Schinz (Apocynaceae), Ekebergia sengalensis A Juss. (Meliaceae), Fragraea fragrans Roxb. (Gentianaceae), Cleistopholis patens (Benth.) Engl. and Diels (Annonaceae) and Spondias mombin L. (Anacardiaceae) [63]. In our study in Kenya we observed, for the first time, larvae of C. forda feeding on E. divinorum, A. mearnsii and Manilkara sulcate, while in DR Congo it feeds mainly on Crossopteryx febrifuga [17]. In West Africa, C. forda is confined on the shea butter tree, Vittelaria paradoxa $[16,29,33]$, whereas in southern Africa host plants include Burkea africana Hook (Fabaceae) and Albizia versicolor Welw. ex Oliv. (Fabaceae) [23].

We collected Go. zambesina from mango and cashew nut trees in Kenya, corroborating earlier findings [12]. Cashew nut and mango trees are important commercial trees whose nuts and fruits, respectively, are widely consumed. Gonimbrasia zambesina is sometimes considered a pest of mango trees [67]. Spraying of mango trees to curb pests may pose a threat to Go. zambesina larvae feeding on the leaves.

Apart from being host plants for edible insects, most of these plants have other uses in communities in Kenya and beyond. For example, E. divinorum is utilized by the Maasai in Kenya as firewood, their stem cuttings are used as toothbrushes and their fruits are edible [68]. Marakwets from the Rift Valley region in Kenya use E. divinorum as antivenom [69] while the Luo from western Kenya use it to treat venereal diseases [70]. Maasai also use $V$. tortilis and $V$. nilotica for firewood [71] while the Marakwet employ them for treating abdominal pains [69]. Balanites spp. are used to treat coughs [70], and finally $A$. mearnsii is often planted for firewood, timber, apiculture and a source of tanning dyes, 
and trees are also used for shade, nitrogen fixation and controlling soil erosion [72]. Such traditional knowledge can be used to encourage communities to conserve these plants and hence protect habitats for edible saturniid species.

\section{Conclusions}

We successfully documented seven species of saturniids in Kenya, among which three are consumed. The identity of these species was confirmed both at molecular and morphological level. Their distribution, seasonality and host plants were also established. We emphasize the importance of combining molecular barcoding, morphological identification, phenology, and ecology studies in identification of edible saturniid species. Potential habitats under current and future climate scenarios of two edible saturniid species, B. alcinoe and $C$. forda, were mapped. This information may help in implementing conservation measures for edible saturniids and their host plants. Due to their seasonal occurrence, further research is required on prospects for mass production to ensure a continuous supply and to prevent overharvesting from the wild forest for enhance sustainability. Moreover, potential economic benefits of edible saturniids for local communities in East Africa need to be quantified and their value chains established.

Supplementary Materials: The following are available online at https://www.mdpi.com/article/10 .3390 /insects12070600/s1, Table S1. Location and agro-ecological zones of the study sites in Kenya; Table S2. Accession numbers of saturniid sequences submitted to the GenBank. Table S3. Pairwise genetic distances of Gonimbrasia zambesina samples. Table S4. Pairwise genetic distances of Bunaea alcinoe samples.

Author Contributions: Conceptualization, E.S.K., C.B., F.M.K., C.M.T. and S.S. methodology, E.S.K., F.M.K., F.L.O., R.S.C. and S.S. validation, C.B., F.M.K., C.M.T. and S.S. formal analysis, E.S.K., F.M.K., F.L.O. and C.M.T. investigation, E.S.K., visualization E.S.K., R.S.C. and C.M.T.; resources, C.B., F.M.K., C.M.T., R.S.C. and S.S. data curation, E.S.K., writing-original draft preparation, E.S.K., writing-review and editing, E.S.K., C.B., F.M.K., C.M.T. and S.S. supervision, C.B. and S.S. project administration, S.S.; funding acquisition, C.B., S.S. All authors have read and agreed to the published version of the manuscript.

Funding: This research was funded by the Federal Ministry for Economic Cooperation and Development (BMZ) (ENTONUTRI-81194993), BioInnovate Africa Programme (INSBIZ-Contribution ID No. 51050076) and Canadian International Development Research Centre (IDRC) and the Australian Centre for International Agricultural Research (ACIAR) (INSFEED - Phase 2: Cultivate Grant No: 108866-001). We also gratefully acknowledge icipe core funding provided by the Foreign, Commonwealth and Development Office (FCDO), Government of the United Kingdom; the Swedish International Development Cooperation Agency (Sida); the Swiss Agency for Development and Cooperation (SDC); Federal Democratic Republic of Ethiopia; the Kenyan Government. The funders had no role in study design, data collection and analysis, decision to publish, or preparation of the manuscript.

Data Availability Statement: DNA sequences for species identification have been deposited in the GenBank (https:/ / www.ncbi.nlm.nih.gov/WebSub / (accessed on 10 March 2020)).

Acknowledgments: The authors wish to thank Maureen Odhiambo, Catherine Awuoche, Richard Obiero and Kentosse Guttu for technical assistance. We wish to thank Alex Musyoki, Ashikoye Okoko and Esther Kioko, National Museum of Kenya for their technical inputs for morphological identification of the specimens.

Conflicts of Interest: The authors declare no conflict of interest. The funders had no role in the design of the study; in the collection, analyses, or interpretation of data; in the writing of the manuscript, or in the decision to publish the results.

\section{References}

1. Van Huis, A.; van Itterbeeck, J.; Klunder, H.; Mertens, E.; Halloran, A.; Muir, G.; Vantomme, P. Edible Insects. Future Prospects for Food and Feed Security; FAO Forestry Paper 171; FAO: Rome, Italy, 2013.

2. Van Huis, A. Potential of Insects as Food and Feed in Assuring Food Security. Annu. Rev. Entomol. 2013, 58, 563-583. [CrossRef] 
3. Di Mattia, C.; Battista, N.; Sacchetti, G.; Serafini, M. Antioxidant activities in vitro of water and liposoluble extracts obtained by different species of edible insects and invertebrates. Front. Nutr. 2019, 6, 106. [CrossRef] [PubMed]

4. Stull, V.J.; Finer, E.; Bergmans, R.S.; Febvre, H.P.; Longhurst, C.; Manter, D.K.; Patz, J.A.; Weir, T.L. Impact of edible cricket consumption on gut microbiota in healthy adults, a double-blind, randomized crossover trial. Sci. Rep. 2018, 8, 10762. [CrossRef] [PubMed]

5. Oonincx, D.G.A.B.; de Boer, I.J.M. Environmental impact of the production of mealworms as a protein source for humans-A life cycle assessment. PLoS ONE 2012, 7, e51145. [CrossRef]

6. Oonincx, D.G.A.B.; van Itterbeeck, J.; Heetkamp, M.J.W.; van den Brand, H.; van Loon, J.J.A.; van Huis, A. An exploration on greenhouse gas and ammonia production by insect species suitable for animal or human consumption. PLoS ONE 2010, 5 , e14445. [CrossRef] [PubMed]

7. Miglietta, P.; De Leo, F.; Ruberti, M.; Massari, S. Mealworms for food: A water footprint perspective. Water 2015, 7, 6190-6203. [CrossRef]

8. Dobermann, D.; Michaelson, L.; Field, L.M. The effect of an initial high-quality feeding regime on the survival of Gryllus bimaculatus (black cricket) on bio-waste. J. Insects Food Feed 2019, 5, 117-123. [CrossRef]

9. Magara, H.J.O.; Tanga, C.M.; Ayieko, M.A.; Hugel, S.; Mohamed, S.A.; Khamis, F.M.; Salifu, D.; Niassy, S.; Sevgan, S.; Fiaboe, K.K.M.; et al. Performance of newly described native edible cricket Scapsipedus icipe (Orthoptera: Gryllidae) on various diets of relevance for farming. J. Econ. Entomol. 2019, 112, 653-664. [CrossRef]

10. Jongema, Y. List of Edible Insects of the World; Wageningen University: Wageningen, The Netherlands, 2017.

11. Kelemu, S.; Niassy, S.; Torto, B.; Fiaboe, K.; Affognon, H.; Tonnang, H.; Maniania, N.K.; Ekesi, S. African edible insects for food and feed: Inventory, diversity, commonalities and contribution to food security. J. Insects Food Feed 2015, 1, 103-119. [CrossRef]

12. Pinhey, E.C.G. The Emperor Moths of Eastern Africa; The East Africa Natural History Society: Nairobi, Kenya, 1956 ; Volume 23.

13. Pinhey, E.C.G. Emperor Moths of South and South Central Africa; C. Struik: Cape Town, South Africa, 1972.

14. Pinhey, E.C.G. Moths of Southern Africa: Descriptions and Colour Illustrations of 1183 Species, 1st ed.; Tafelberg Publishers Ltd.: Cape Town, South Africa, 1975.

15. Ande, A.T. The influence of local harvesting and processing methods on some nutrient content of Cirina forda Westwood (Lepidoptera: Saturniidae) in Nigeria. Niger. J. Pure Appl. Sci. 2002, 17, 1165-1168.

16. Badanaro, F.; Amevoin, K.; Lamboni, C.; Kou'santa, A. Edible Cirina forda (Westwood, 1849) (Lepidoptera: Saturniidae) caterpillar among Moba people of the Savannah Region in North Togo: From collector to consumer. Asian J. Appl. Sci. Eng. $2014,3$. [CrossRef]

17. Latham, P. Edible Caterpillars and Their Food Plants in Bas-Congo Province, Democratic Republic of Congo, 3rd ed.; Paul Latham: Perthshire, UK, 2015; p. 44.

18. Glew, R.H.; Jackson, D.; Sena, L.; VanderJagt, D.J.; Pastuszyn, A.; Millson, M. Gonimbrasia belina (Lepidoptera: Saturniidae): A nutritional food source rich in protein, fatty acids, and minerals. Am. Entomol. 1999, 45, 250-253. [CrossRef]

19. Makhado, R.; Potgieter, M.; Timberlake, J.; Gumbo, D. A review of the significance of mopane products to rural people's livelihoods in Southern Africa. Trans. R. Soc. South Afr. 2014, 69, 117-122. [CrossRef]

20. Baiyegunhi, L.J.S.; Oppong, B.B. Commercialisation of mopane worm (Imbrasia belina) in rural households in Limpopo Province, South Africa. For. Policy Econ. 2016, 62, 141-148. [CrossRef]

21. Hlongwane, Z.T.; Slotow, R.; Munyai, T.C. Nutritional composition of edible insects consumed in Africa: A systematic review. Nutrients 2020, 12, 2786. [CrossRef]

22. Scoble, M. The Lepidoptera Form Function, and Diversity; Oxford University Press: New York, NY, USA, 1992.

23. Oberprieler, R. The Emperor Moths of Namibia; Ekogilde: Pretoria, South Africa, 1995.

24. Stack, J.; Dorward, A.; Gondo, T.; Frost, P.; Taylor, F.; Kurebgaseka, N. Mopane worm utilisation and rural livelihoods in Southern Africa. In Proceedings of the International Conference on Rural Livelihoods, Forests and Biodiversity, Bonn, Germany, 19-23 May 2003.

25. Fasoranti, J.O.; Ajiboye, D.O. Some edible insects of Kwara state, Nigeria. Entomol. Soc. Am. 1993, 39, 113-116. [CrossRef]

26. Defoliart, G.R. Edible insects as minilivestock. Biodivers. Conserv. 1995, 4, 306-321. [CrossRef]

27. Nyoka, B.I. State of Forest and Tree Genetic Resources in Dry Zone Southern Africa Development Community Countries; Working Paper FGR/41E; Food and Agriculture Organization of the United Nations: Rome, Italy, 2003.

28. Ditlhogo, M. The Natural History of Imbrasia belina (Westwood) (Lepidoptera: Saturniidae) and Some Factors Affecting Its Abundance in North-Eastern Botswana. Ph.D. Thesis, University of Manitoba, Winnipeg, MB, Canada, 1996.

29. Ande, A.T.; Fasoranti, J.O. Life history notes for the pallid emperor moth, Cirina forda (Westwood) (Lepidoptera: Saturniidae). J. Lepidoterists Soc. 1997, 51, 269-271.

30. Balinga, M.; Mapunzu, P.M.; Moussa, J.B.; N'Gasse, G. Contribution Des Insectes De La Forêt À La Sécurité Alimentaire: L'exemple Des Chenilles d'Afrique Centrale; Food and Agriculture Organization of The United Nations: Rome, Italy, 2004; p. 117. (In French)

31. Moruakgomo, M.B.W. Commercial utilization of Botswana's veld products the economics of phane: The dimensions of phane trade. In Proceedings of the First Multidisciplinary Symposium on Phane, Gaborone, Botswana, 18 June 1996; The Department of Biological Sciences and the Kalahari Conservation Society: Gaborone, Botswana, 1996; pp. 23-31.

32. Ande, A.T.; Fasoranti, J.O. Some aspects of the biology, foraging and defensive behaviour of the emperor moth caterpillar, Cirina forda (Westwood). Int. J. Trop. Insect Sci. 1998, 18, 177-181. [CrossRef] 
33. Dwomoh, E.A.; Ahadzie, S.K.; Agene, V.N.; Somuah, G.A.; Ackonor, J.B. Biology and phenology of the shea tree defoliator Cirina forda (Westwood) (Lepidoptera: Saturniidae) in Northern Ghana. Ghana J. Hortic. 2010, 8, 55-64.

34. Omotoso, O.T. Nutritional quality, functional properties and anti-nutrient compositions of the larva of Cirina forda (Westwood) (Lepidoptera: Saturniidae). J. Zhejiang Univ. Sci. B 2006, 7, 51-55. [CrossRef]

35. Womeni, H.M.; Linder, M.; Tiencheu, B.; Mbiapo, F.T.; Villeneuve, P.; Fanni, J.; Parmentier, M. Oils of insects and larvae consumed in Africa: Potential sources of polyunsaturated fatty acids. Ol. Corps Gras Lipides 2009, 16, 230-235. [CrossRef]

36. Adepoju, O.T.; Daboh, O.O. Nutrient composition of Cirina forda (Westwood)-enriched complementary foods. Ann. Nutr. Metab. 2013, 63, 139-144. [CrossRef] [PubMed]

37. Vantomme, P.; Göhler, D.; N’Deckere-Ziangba, F. Contribution of Forest Insects to Food Security and Forest Conservation: The Example of Caterpillars in Central Africa; Food and Agriculture Organization of The United Nations: Rome, Italy, $2004 ;$ p. 4.

38. Sombroek, W.G.; Braun, H.M.H.; van der Pouw, B.J.A. Exploratory Soil Map and Agro-Climatic Zone Map of Kenya; Ministry of Agriculture: Nairobi, Kenya, 1982; p. 56.

39. FAO. Agro-Ecological Zoning Guidelines; FAO Soils Bulletin; Food and Agriculture Organization of the United Nations: Rome, Italy, 1996; p. 78.

40. Kuhne, L. Butterflies and Moth Diversity of the Kakamega Forest; Selbstverl: Postdam, Germany, 2008.

41. Goff, R. African Moths. Available online: https://www.africanmoths.com/ (accessed on 26 September 2019).

42. Beentje, H.; Adamson, J.; Bhanderi, D. Kenya Trees, Shrubs, and Lianas; National Museums of Kenya: Nairobi, Kenya, 1994.

43. Hebert, P.D.N.; Penton, E.H.; Burns, J.M.; Janze, D.H.; Hallwachs, W. Ten species in one: DNA barcoding reveals cryptic species in the neotropical skipper butterfly Astraptes fulgerator. Proc. Natl. Acad. Sci. USA 2004, 101, 14812-14817. [CrossRef] [PubMed]

44. Hall, T.A. BioEdit: A user-friendly biological sequence alignment editor and analysis program for Windows 95/98/NT. Nucleic Acids Symp. 1999, 41, 95-98.

45. Altschul, S.F.; Gish, W.; Miller, W.; Myers, E.W.; Lipman, D.J. Basic local alignment search tool. J. Mol. Biol. 1990, $215,403-410$. [CrossRef]

46. Rantnasingham, S.; Herbert, P.D.N. Bold: The barcode of life data system. Mol. Ecol. Notes 2007, 7, 355. [CrossRef]

47. Thompson, J.D.; Higgins, D.G.; Gibson, T.J. CLUSTAL W: Improving the sensitivity of progressive multiple sequence alignment through sequence weighting, position-specific gap penalties and weight matrix choice. Nucleic Acids Res. 1994, 22, 4673-4680. [CrossRef]

48. Kumar, S.; Stecher, G.; Li, M.; Knyaz, C.; Tamura, K. MEGA X: Molecular evolutionary genetics analysis across computing platforms. Mol. Biol. Evol. 2018, 1547-1549. [CrossRef]

49. Dauda, B.E.N.; Mathew, J.T.; Paiko, Y.B.; Ndamitso, M.M. Nutritive and anti-nutritive composition of locust bean tree emperor moth larvae Bunaea alcinoe (Lepidoptera-Saturniidae Stoll 1780) from Gurara local government area, Niger state, Nigeria. J. Sci. Res. Rep. 2014, 3, 1771-1779. [CrossRef]

50. Paiko, Y.B.; Jacob, J.O.; Salihu, S.O.; Dauda, B.E.N.; Suleiman, M.A.T.; Akanya, H.O. Fatty acid and amino acid profile of emperor moth caterpillar (Cirina forda) in Paikoro local government area of Niger state, Nigeria. Am. J. Biochem. 2014, 4, 29-34.

51. Mabossy-Mobouna, G.; Bouyer, T.; Latham, P.; Roulon-Doko, P.; Konda Ku Mbuta, A.; Malaisse, F. Preliminary knowledge for breeding edible caterpillars in Congo-Brazzaville. Geo Eco Trop Rev. Int. Géol. Géograph. Écol. Trop. 2016, 40, 145-174.

52. Agbidye, F.S.; Ofuya, T.I.; Akindele, S.O. Marketability and nutritional qualities of some edible forest insects in Benue state, Nigeria. Pak. J. Nutr. 2009, 8, 917-922. [CrossRef]

53. Ehounou, G.P.; Ouali-N'goran, S.W.M.; Niassy, S. Assessment of entomophagy in Abidjan (Cote Divoire, West Africa). Afr. J. Food Sci. 2018, 12, 6-14. [CrossRef]

54. Ngute, A.S.K.; Dongmo, M.A.K.; Effa, J.A.M.; Onguene, E.M.A.; Lontchi, J.F.; Cuni-Sanchez, A. Edible caterpillars in central Cameroon: Host plants, value, harvesting, and availability. For. Trees Livelihoods 2020, 29, 16-33. [CrossRef]

55. Phillips, S.J.; Anderson, R.P.; Schapire, R.E. Maximum entropy modeling of species geographic distributions. Ecol. Model. 2006, 190, 231-259. [CrossRef]

56. Muscarella, R.; Galante, P.J.; Soley-Guardia, M.; Boria, R.A.; Kass, J.M.; Uriarte, M.; Anderson, R.P. ENMeval: An R package for conducting spatially independent evaluations and estimating optimal model complexity for maxent ecological niche models. Methods Ecol. Evol. 2014, 5, 1198-1205. [CrossRef]

57. Swets, J.A. Measuring the accuracy of diagnostic systems. Science 1988, 240, 1285-1293. [CrossRef]

58. Wei, B.; Wang, R.; Hou, K.; Wang, X.; Wu, W. Predicting the current and future cultivation regions of Carthamus tinctorius L. using MaxEnt model under climate change in China. Glob. Ecol. Conserv. 2018, 16, e00477. [CrossRef]

59. Mbata, K.J.; Chidumayo, E.N.; Lwatula, C.M. Traditional regulation of edible caterpillar exploitation in the Kopa area of Mpika district in northern Zambia. J. Insect Conserv. 2002, 6, 115-130. [CrossRef]

60. Amadi, E.N.; Ogbalu, O.K.; Barimalaa, I.S.; Pius, M. Microbiology and nutritional composition of an edible larva (Bunaea alcinoe Stoll) of the Niger delta. J. Food Saf. 2005, 25, 193-197. [CrossRef]

61. Temitope, A.O.; Job, O.O.; Abiodun, A.-F.T.; Dare, A.O. Eco-diversity of edible insects of Nigeria and its impact on food security. J. Biol. Life Sci. 2014, 5, 175-187. [CrossRef]

62. Kachapulula, P.W.; Akelo, J.; Bandyopathyay, R.; Cotty, P.J. Aflatoxin contamination of dried insects and fish in Zambia. J. Food Prot. 2018, 81, 1508-1518. [CrossRef] 
63. Siozios, S.; Massa, A.; Parr, C.L.; Verspoor, R.L.; Hurst, G.D.D. DNA barcoding reveals incorrect labelling of insects sold as food in the UK. PeerJ 2020, 8. [CrossRef]

64. Akanbi, M.O. Comparing two saturniid defoliators of Holarrhena floribunda and Ekebergia sengalensis, respectively, with notes on their natural enemies. J. Nat. Hist. 1973, 7, 307-318. [CrossRef]

65. Thomas, B. Sustainable harvesting and trading of mopane worms (Imbrasia belina) in northern Namibia: An experience from the Uukwaluudhi area. Int. J. Environ. Stud. 2013, 70, 494-502. [CrossRef]

66. Kwiri, R.; Winini, C.; Muredzi, P.; Tongonya, J.; Gwala, W.; Mujuru, F.; Gwala, S.T. Mopane worm (Gonimbrasia belina) utilisation, a potential source of protein in fortified blended foods in Zimbabwe: A review. Glob. J. Sci. Front. Res. 2014, 14, 1-14.

67. De Almeida, D.M. Pests of Mango. Gaz. Agric. 1972, 24, 2-5.

68. Bussmann, R.W.; Gilbreath, G.G.; Solio, J.; Lutura, M.; Lutuluo, R.; Kunguru, K.; Wood, N.; Mathenge, S.G. Plant use of the Maasai of Sekenani valley, Maasai Mara, Kenya. J. Ethnobiol. Ethnomedicine 2006, 2, 22. [CrossRef]

69. Kipkore, W.; Wanjohi, B.; Rono, H.; Kigen, G. A study of the medicinal plants used by the Marakwet community in Kenya. J. Ethnobiol. Ethnomed. 2014, 10, 24. [CrossRef]

70. Johns, T.; Kokwaro, J.O.; Kimanani, E.K. Herbal remedies of the Luo of Siaya district, Kenya: Establishing quantitative criteria for consensus. Econ. Bot. 1990, 44, 369-381. [CrossRef]

71. Tian, X. Ethnobotanical knowledge acquisition during daily chores: The firewood collection of pastoral Maasai girls in southern Kenya. J. Ethnobiol. Ethnomed. 2017, 13, s13002-s13016. [CrossRef] [PubMed]

72. Orwa, C.; Mutua, A.; Kindt, R.; Jamnadass, R.; Anthony, S. Agroforestry Database: A Tree Reference and Selection Guide Version 4.0; World Agroforestry Centre: Nairobi, Kenya, 2009. 